\title{
Modeling the Hydrogeochemical Processes and Source of Ions in the Groundwater of Aquifers within Kasra-Nukhaib Region (West Iraq)
}

\author{
Bayan Muhie Hussien', Abed Salih Faiyad² \\ ${ }^{1}$ College of Applied Sciences, University of Anbar, Hit, Iraq \\ ${ }^{2}$ College of Pure Sciences, University of Anbar, Ramadi, Iraq \\ Email: bayan1959@yahoo.com
}

How to cite this paper: Hussien, B.M. and Faiyad, A.S. (2016) Modeling the Hydrogeochemical Processes and Source of Ions in the Groundwater of Aquifers within KasraNukhaib Region (West Iraq). International Journal of Geosciences, 7, 1156-1181. http://dx.doi.org/10.4236/ijg.2016.710087

Received: August 26, 2016

Accepted: October 17, 2016

Published: October 20, 2016

Copyright $\odot 2016$ by authors and Scientific Research Publishing Inc. This work is licensed under the Creative Commons Attribution International License (CC BY 4.0).

http://creativecommons.org/licenses/by/4.0/ (c) (i) Open Access

\section{Abstract}

Hydrogeological investigation of groundwater has been performed within KasraNukhaib district (west Iraq). The physicochemical analyses of the groundwater samples collected from Um Erdhuma-Tayarat aquifer are used in determination of hydrogeochemical processes, hydrochemical facies, hydrochemical ratio, and saturation indices supported by phreeqc software. The monitoring network of groundwater quality consists of twelve physiochemical variables in twenty four water wells were determined, aiming to examine the hydrogeo-chemical phenomena which are benefit in groundwater development and support the plans of future uses (exploitation) and groundwater management. A hydrogeological model was prepared to examine qualitative evaluation of aquifers media related to geochemical processes. Spatial hydrochemical bi-models were achieved for quantitative interpretation. Various graphical plots such as Piper, Durov, and Gibbs diagrams are used in proving different geochemical processes. The results are correlated with standards classifications to deduce the hydrogeo-chemical phenomena. The results showed that the groundwater of Um Erdhuma-Tayarat aquifer has a property of Carbonate weathering represents the major hydrogeochemical processes. In addition, ion exchange and reverse ion exchange were two possible processes of water-rock interaction (e.g. dolomitization processes) within the hydrogeologic system. Also, the evaporation process and mixing action of recharge vadose waters, and ancient trapped fossil waters have a moderate effect on the evolution of groundwater quality. An increased salt content is observed in groundwater at different static water levels indicating mixing with various sources. The mechanism controlling groundwater chemistry is originally related to geogenic process. In addition, anthropogenic activities have not significantly altered 
the geochemical nature of groundwater in the aquifers system.

\section{Keywords}

Groundwater, Ion Exchange, Water-Rock Interaction, Geochemical Process

\section{Introduction}

The study involved a selected area located between longitude $42^{\circ} 00^{\prime} 00^{\prime \prime}$ to $42^{\circ} 30^{\prime} 00^{\prime \prime}$ and latitude $32^{\circ} 00^{\prime} 00^{\prime \prime}$ to $32^{\circ} 30^{\prime} 00^{\prime \prime}$ with a total area of $2600 \mathrm{~km}^{2}$ and elevation ranges between 280 and 360 meters above sea level Figure 1. The hydrogeochemical data of groundwaters of Um Erdhuma-Tayarat aquifer were examined to determine the factors that control the groundwater chemistry and the hydro-geochemical evolution.

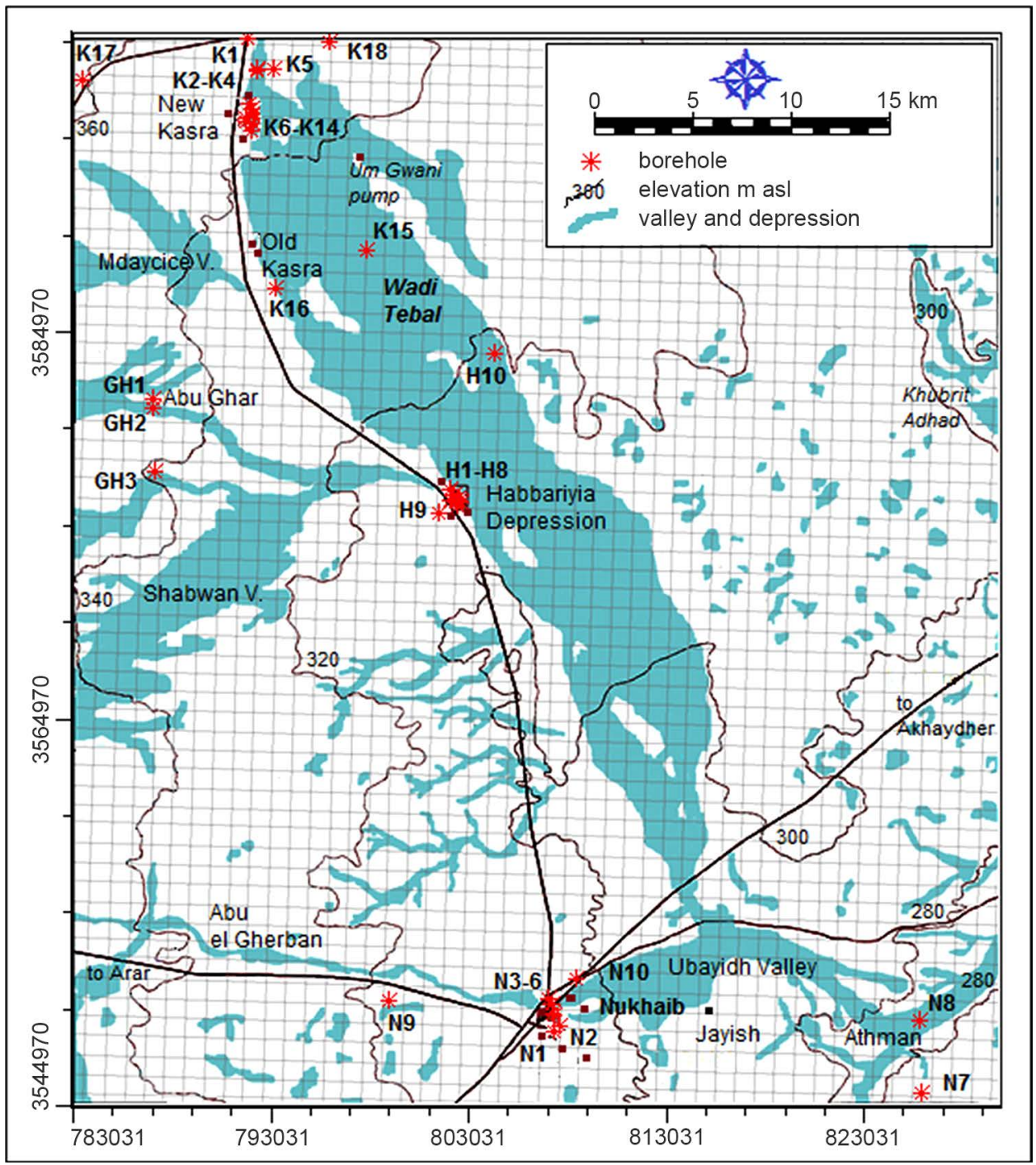

Figure 1. Location map of the study area. 
Different geochemical interpretation methods were used to identify the geochemical characteristics. The study aims to estimate the hydrogeochemical processes using hydrochemical ratios and indices, also to determine the geochemical assessment and hydrochemical characteristics of the groundwater, which would be support planners in validating groundwater quality models. The area of investigation characterised by dry desert climate (dry Arid zone) during the second half of the twentieth century and the first decade of the twenty-first century [1], where the mean annual values of rainfalls are not exceeding $50 \mathrm{~mm}$ in some dry years and little quantities of water may flow. The study area has undulating terrain with land surface rises gradually from the SE to the NW. The slope of the land surface varies between 0.4 and $13 \mathrm{~m} / \mathrm{km}$. Several valleys of seasonal flux forming plateaus with pediment deposits [2] and depression filled with sediments such as Habbariyia, Shabwan, and Khubrit Adhad. The valleys are defined as main landforms including Ubayidh valley and Tebal valley with its tributaries (Mdaycice, Abu Ghar, Shabwan, and Dwaykhla), these valleys form important drainage basins feeder to Um Erdhuma-Tayarat aquifer (groundwater recharge zone) (Figure 1).

The valleys and depressions fill sediments are considered as important geomorphologic units which classified within the scope of the territory eligible for agricultural activities. The depressions fill sediment overlies varying areas originated to the leaching of fractured dolomite and limestone rocks, where active runoff contributes in filling depressions by sands, mud, and silts. These valleys are characterized by expanding of widths, presence of old soils with gravels aggregates, karst sinkholes, rocks creep, and presence of meandering valleys with many break off in their long sectors.

In Habbariyia Depression, three stages of alluvial fans are developed. The higher two stages are highly dissected and separated from each other by a cliff. The two stages are probably of Pleistocene age. The third stage (youngest) is of smooth surface and might be of Early Holocene age. Structurally, the study area is located in the SE limb of Hauran anticlinorium (Rutba Uplift) within the Arabic-African plate [3].

The uplift contributed to the tectonic movements within successive geological periods affects the structural and stratigraphic settings within Nukhaib Graben. Reference [4] described the N-S trending faults as a set of normal faults system with nearly 160 Kilometers in long and 60 Kilometers in wide forming Nukhaib Graben. Reference [5] presented an extended discussion concerning the geology and origin of Nukhaib Graben, using different geological, geophysical, and geochemical data. They pointed out that the graben is formed above the basement high of granitic intrusion and/or salt dome.

The software (Rockware-14) is used to determine the Hydro-structural model, based on geological data. The result of the model (Figure 2) shows the horizontal and vertical extension of geological formations within the geo-structural situation of the region related to the movement of the base blocks within Hail arch during Paleozoic. Also, Jurassic, Cretaceous, and Tertiary beds dip from $1.0^{\circ}$ to $2.0^{\circ}$ in a direction of ESE within the south eastern limb of Hauran anticlinorium.

Geological studies of [6]-[12], are summarized in a spatial distribution map of the 


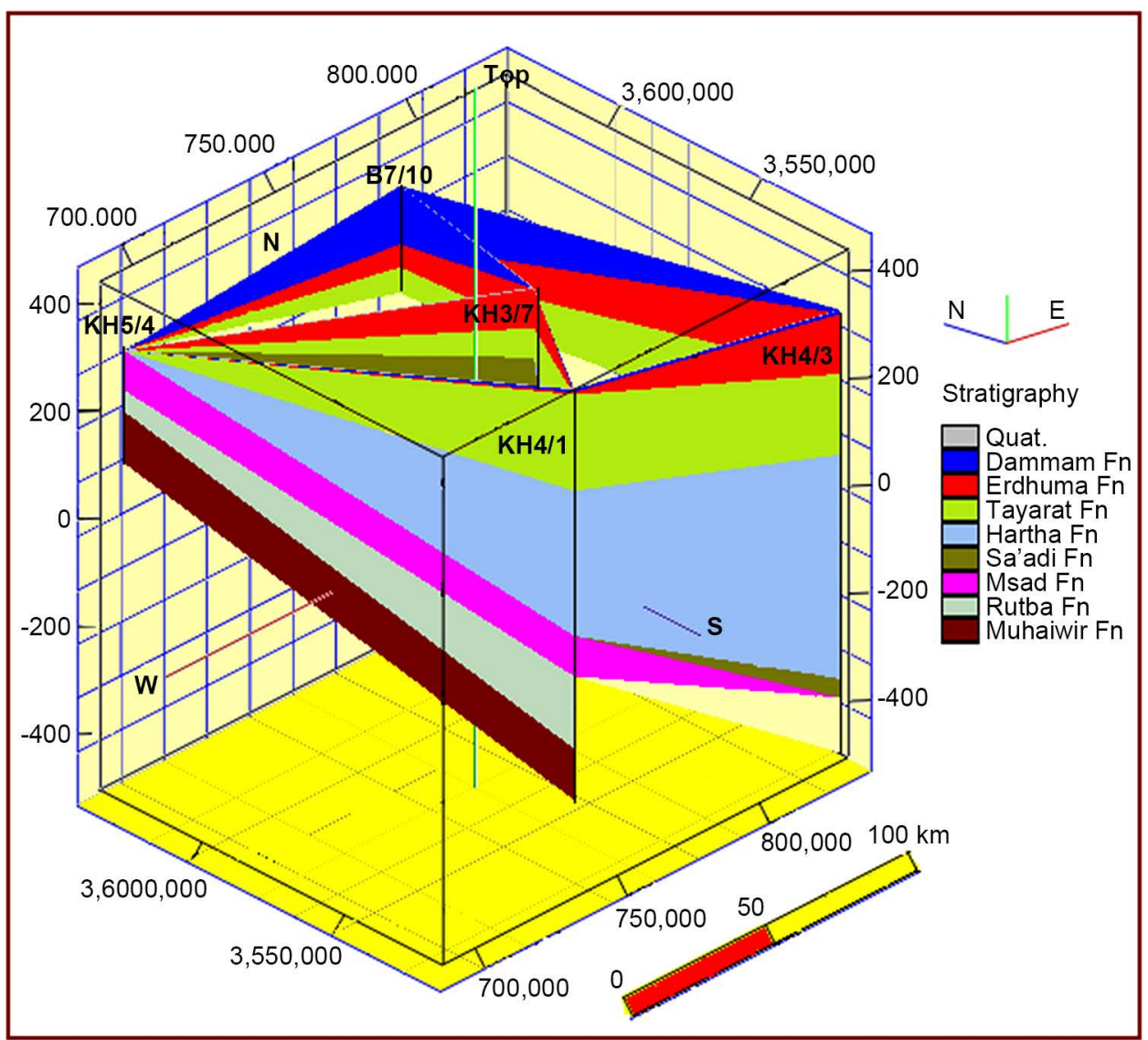

Figure 2. Geo-structural model of the study area.

Geologic Formations (Figure 3), and illustrated by vertical extensions as shown in the geological section A-B (Figure 4), where the study area includes Quaternary sediments, Zahra Formation, Dammam Formation, Erdhuma Formation, Tayarat Formation, Hartha Formation, Saadi Formation, Msad Formation, Rutba Formation, and Muhaywir Formation. More geologic details are mentioned in Table 1.

Groundwater occurs in different water bearing horizons of karistic fractured carbonate rocks belonging to Late Maestrichtian-Danian Formations (UmErdhuma-Tayarat aquifer). Regionally, al Hamad physiographic zone is considered as a main recharge zone of the aquifer within study area, [3] [14], these studies confirmed a practical occurrence of recharge and water replenishment renewed aquifers by rain and runoff waters penetrated throughout rocks exposures within the valleys. Locally, UmErdhuma-Tayarat aquifer is recharged from Tebal-Ubayidh catchment area and from lateral leakage of waters passing as a result of hydraulic connection between adjacent aquifers. The amount of infiltration penetrated to UmErdhuma-Tayarat aquifer within study area is equal to:

$$
\begin{aligned}
\text { Amount of infiltration } & =\text { infiltration rate } \times \text { area } \\
& =0.00238 \mathrm{~m} / \text { year } \times 2600 \times 10^{6} \mathrm{~m}^{2} \\
& =6.188 \times 10^{6} \mathrm{~m}^{3} / \text { year },[1]
\end{aligned}
$$




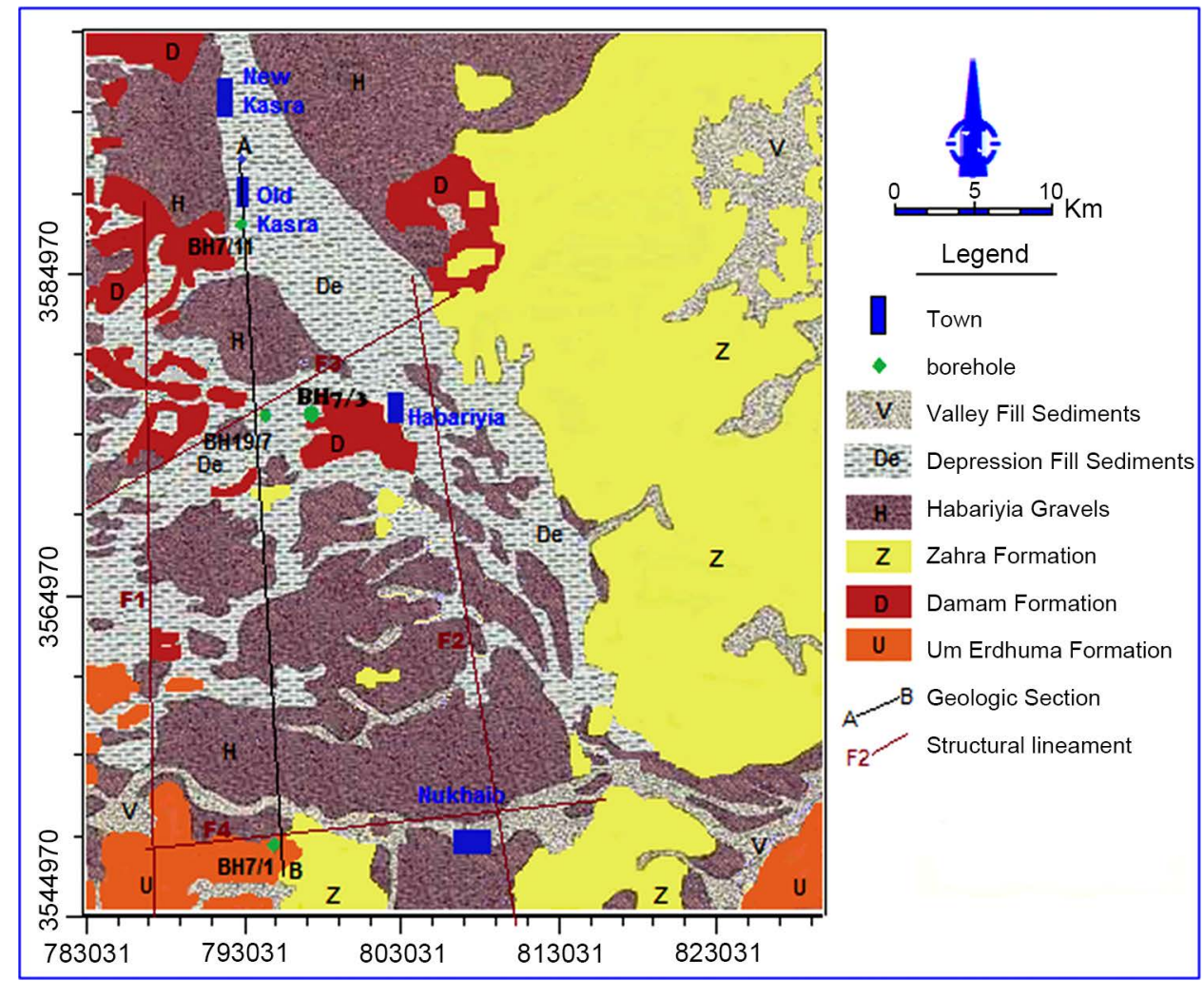

Figure 3. Spatial distribution map of the Geologic Formations.

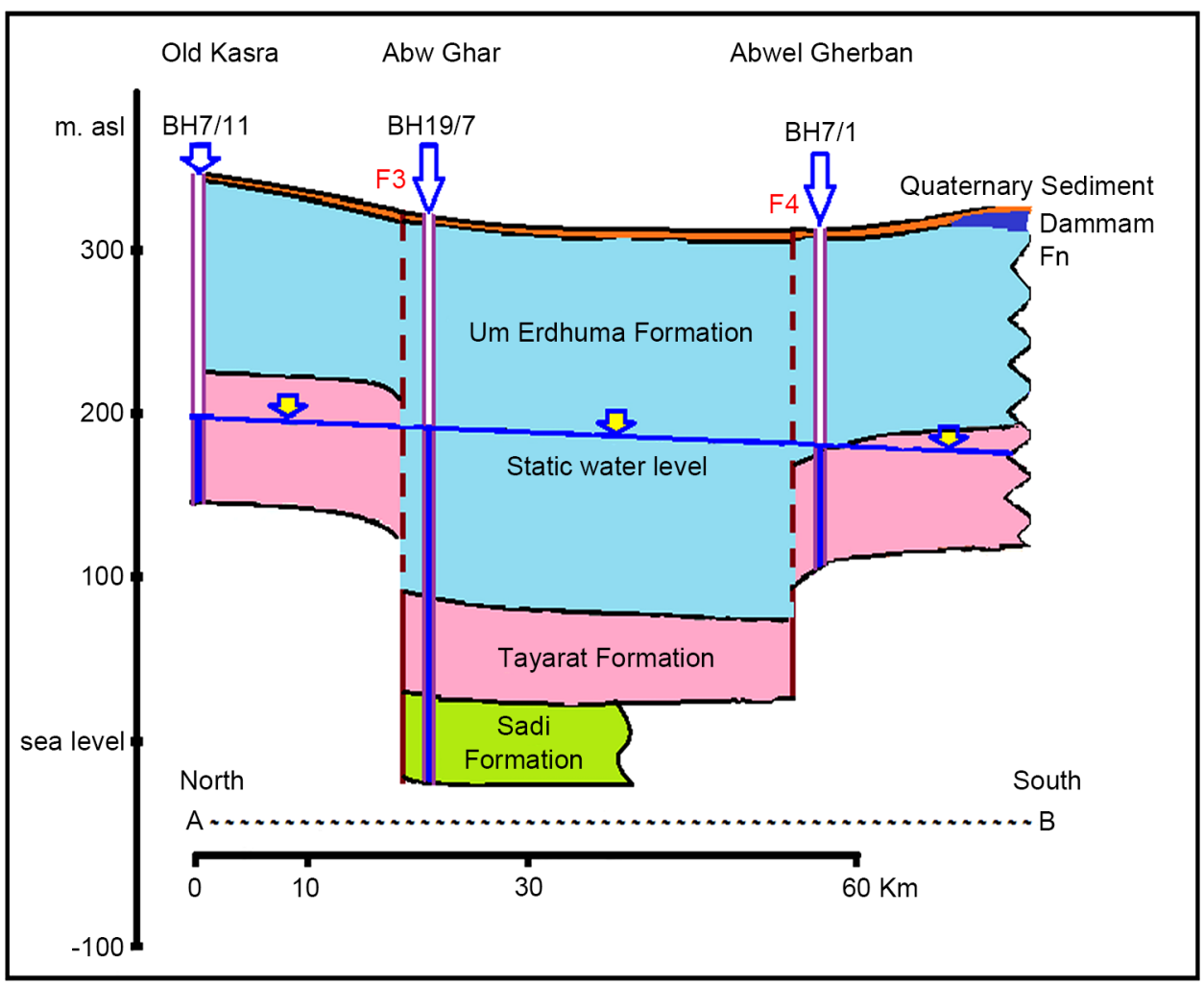

Figure 4. Lateral and vertical hydrogeologic extension within study area [13]. 
Table 1. Geologic Information of Kasra-Nukhaib region.

\begin{tabular}{|c|c|c|c|c|}
\hline Era & Period & Age & Formation & Explanation \\
\hline \multirow{6}{*}{ Cenozoic } & \multirow[t]{2}{*}{ Quaternary } & Holocene-Pleistocene & Recent deposits & $\begin{array}{l}\text { Alluvial sediments, valley, } \\
\text { depression fill sediments. }\end{array}$ \\
\hline & & Pleistocene & Habbariyia Gravel & sandy Gravel, Conglomerate \\
\hline & \multirow{4}{*}{ Tertiary } & Late Miocene-Pliocene & Zahra Formation & $\begin{array}{l}\text { Limestone, calcareous sandstones } \\
\text { with hard recrystallized carbonates }\end{array}$ \\
\hline & & & & \\
\hline & & Lutetian & Dammam Fn. & $\begin{array}{c}\text { Fossiliferous limestone and dolomitic } \\
\text { limestone alternations with clays } \\
\text { chalky and cherty limestone }\end{array}$ \\
\hline & & Danian & Um Erdhuma Fn. & $\begin{array}{l}\text { Phosphatic limestone, dolomite, } \\
\text { dolomitic limestone, and thin } \\
\text { beds of anhydrite. }\end{array}$ \\
\hline \multirow{6}{*}{ Mesozoic } & \multirow{5}{*}{ Cretaceous } & Late Maestrichtian & Tayarat Fn. & $\begin{array}{l}\text { Limestone, yellow marl, dolomite, } \\
\text { dolomitic limestone, and phosphatic } \\
\text { siliceous limestone. }\end{array}$ \\
\hline & & $\begin{array}{l}\text { Late Campanian-Early } \\
\text { Maestrichtian }\end{array}$ & Hartha Formation & $\begin{array}{c}\text { Sandy limestone, dolomitic limestone } \\
\text { and clayey dolostone interbedded } \\
\text { with marly limestone }\end{array}$ \\
\hline & & $\begin{array}{l}\text { Turonian-early } \\
\text { Campanian }\end{array}$ & Saadi Formation & $\begin{array}{c}\text { Chalky Fossiliferous limestone, marly } \\
\text { limestone and organic limestone. }\end{array}$ \\
\hline & & Cenomanian-Turonian & Msad Formation & $\begin{array}{l}\text { Coralline limestone, multi colored } \\
\text { sandy dolostone, sandy marl } \\
\text { and dolomitic limestone. }\end{array}$ \\
\hline & & Cenomanian & Rutba Formation & $\begin{array}{l}\text { Sandstones alternating with clayey } \\
\text { silty sands, obtained coarse sands, } \\
\text { and basal conglomerate. }\end{array}$ \\
\hline & Jurassic & Bathonian & Muhaywir Fn. & $\begin{array}{l}\text { Dolomitic sandstone, fine ferruginous } \\
\text { sands, limestone, marly limestone } \\
\text { with conglomerate and cherty Clay. }\end{array}$ \\
\hline
\end{tabular}

In the interiors area restricted to Habbariyia-Nukhaib depression, UmErdhumaTayarat aquifer is of unconfined condition with saturation thickness ranged from 52 to 150 meters. The extensions of the aquifer are shown in Figure 2 and Figure 4.

The amount of permeability for the water bearing horizons of UmErdhuma-Tayarat aquifer ranged between $0.1 \mathrm{~m} /$ day and $14.7 \mathrm{~m}$ /day (Table 2). The aquifer is classified as aquifer of low to middle permeability compared with Laboutka classification [15] (Table 3).

The variation in the values of permeability originated to the heterogeneity of the rocks forming aquifers due to fractures density and intensity of karistification. Spatial distribution map of permeability (Figure 5), shows increasing in permeability variation grade ranged between 0.000011 and $0.0095 \mathrm{~m} /$ day/meter distance towards old Kasra 
Table 2. Hydrogeological data of the study area.

\begin{tabular}{|c|c|c|c|c|c|c|c|c|c|c|c|}
\hline St. Id. & $\begin{array}{l}\text { X coordinate } \\
\mathrm{m}\end{array}$ & $\begin{array}{c}\text { Y coordinate } \\
\mathrm{m}\end{array}$ & $\begin{array}{c}\text { Elevation } \\
\mathrm{m} \text { asl }\end{array}$ & $\begin{array}{l}\text { Well Depth } \\
\text { (m) }\end{array}$ & $\begin{array}{c}\text { Depth of } \\
\text { water }(\mathrm{m})\end{array}$ & $\begin{array}{l}\text { SWL } \\
\mathrm{m} \text { asl }\end{array}$ & $\begin{array}{c}\text { Flow Rate } \\
\mathrm{m}^{3} / \text { day }\end{array}$ & $\begin{array}{c}\mathrm{K} \\
\mathrm{m} / \text { day }\end{array}$ & $\begin{array}{c}\mathrm{T} \\
\mathrm{m}^{2} / \text { day }\end{array}$ & $\begin{array}{l}\text { Sp. Cap. } \\
\text { 1/ sec/m }\end{array}$ & Storativity \\
\hline $\mathrm{H} 1$ & $802,476.595$ & $3,575,971.446$ & 308 & 200 & 138 & 170 & 176 & 7.2 & 410 & 8.2 & 0.05 \\
\hline $\mathrm{H} 2$ & $802,654.2798$ & $3,576,161.809$ & 310 & 200 & 139 & 171 & 172.8 & $7.6^{*}$ & $435^{*}$ & 7.8 & l \\
\hline $\mathrm{H} 3$ & $802,545.8857$ & $3,576,281.918$ & 306 & I & 132 & 172 & 173 & 7.8 & 450 & 12 & 0.04 \\
\hline H5 & $802,464.5918$ & $3,576,372$ & 303 & I & 138 & 171 & 172.8 & 7.7 & 430 & 8.8 & I \\
\hline H6 & $802,302.9311$ & $3,576,521.354$ & 305 & 220 & 136 & 169 & 174 & 5.9 & 425 & 10 & 0.001 \\
\hline $\mathrm{H} 7$ & $802,084.3165$ & $3,576,823.203$ & 304 & 220 & 134 & 170 & 178 & I & I & 11.8 & I \\
\hline N1 & $807,385.3354$ & $3,548,825.99$ & 316 & 220 & 121 & 195 & 518.4 & 1.41 & 140 & 5.1 & 0.004 \\
\hline $\mathrm{N} 2$ & $807,666.6056$ & $3,549,081.196$ & 310 & 220 & 111 & 199 & 604.8 & 1.4 & 250 & 3.7 & I \\
\hline N3 & $807,307.7503$ & $3,549,656.321$ & 312 & 220 & 115 & 197 & 518.4 & $1.9^{*}$ & $200^{*}$ & 2 & 0.035 \\
\hline $\mathrm{N} 4$ & $807,225.3003$ & $3,549,777.193$ & 306 & 200 & 109 & 197 & 518.4 & 1.86 & 170 & 3.6 & $0.005^{\star}$ \\
\hline N5 & $807,045.5439$ & $3,550,511.924$ & 306 & 198 & 113 & 193 & 518.4 & 1.3 & 150 & 4 & I \\
\hline N6 & $807,211.3612$ & $3,550,239.367$ & 304 & 220 & 112 & 192 & 518.4 & $0.9^{*}$ & $100^{*}$ & 5.2 & $0.009^{*}$ \\
\hline K3 & $792,336.7511$ & $3,598,522.871$ & 343 & 200 & 159 & 184 & 732 & 14.7 & 580 & 17 & $0.008^{*}$ \\
\hline K4 & $792,362.8658$ & $3,598,523.633$ & 346 & 200 & 160 & 186 & 660 & $13.6^{*}$ & $600^{*}$ & I & I \\
\hline K5 & $793,197.6383$ & $3,598,578.875$ & 345 & 200 & 155 & 190 & 712 & 14.2 & 540 & 15.7 & 0.009 \\
\hline K6 & $790,424.5947$ & $3,596,863.72$ & 341 & 200 & 158 & 183 & 518.4 & 9.9 & 535 & I & I \\
\hline K7 & $790,510.0965$ & $3,596,619.503$ & 343 & 220 & 160 & 183 & 518.4 & $11.3^{*}$ & $610^{*}$ & 16.6 & $0.003^{*}$ \\
\hline K8 & $790,646.9483$ & $3,596,407.613$ & 345 & 220 & 165 & 180 & 691 & l & 520 & l & l \\
\hline K9 & $790,675.7491$ & $3,596,315.937$ & 348 & 220 & 166 & 182 & 604.8 & 12.2 & 610 & I & 0.007 \\
\hline K10 & $790,733.3518$ & $3,596,132.586$ & 346.6 & 200 & 158 & 188.6 & 620 & $12.6^{*}$ & $560^{*}$ & 13.9 & l \\
\hline K11 & $790,611.6809$ & $3,595,820.689$ & 344.5 & 200 & 150 & 194.5 & 518.4 & 10.9 & I & 19.3 & $0.004^{*}$ \\
\hline K12 & $790,517.9093$ & $3,595,447.929$ & 340.6 & 220 & 143.1 & 197.5 & 511 & $9.7^{*}$ & $566^{*}$ & 21.1 & I \\
\hline $\mathrm{K} 13$ & $790,267.6406$ & $3,595,964.905$ & 339.6 & 200 & 157 & 182.6 & 604.8 & $14.6^{*}$ & $512^{*}$ & 21 & 0.01 \\
\hline
\end{tabular}


Continued

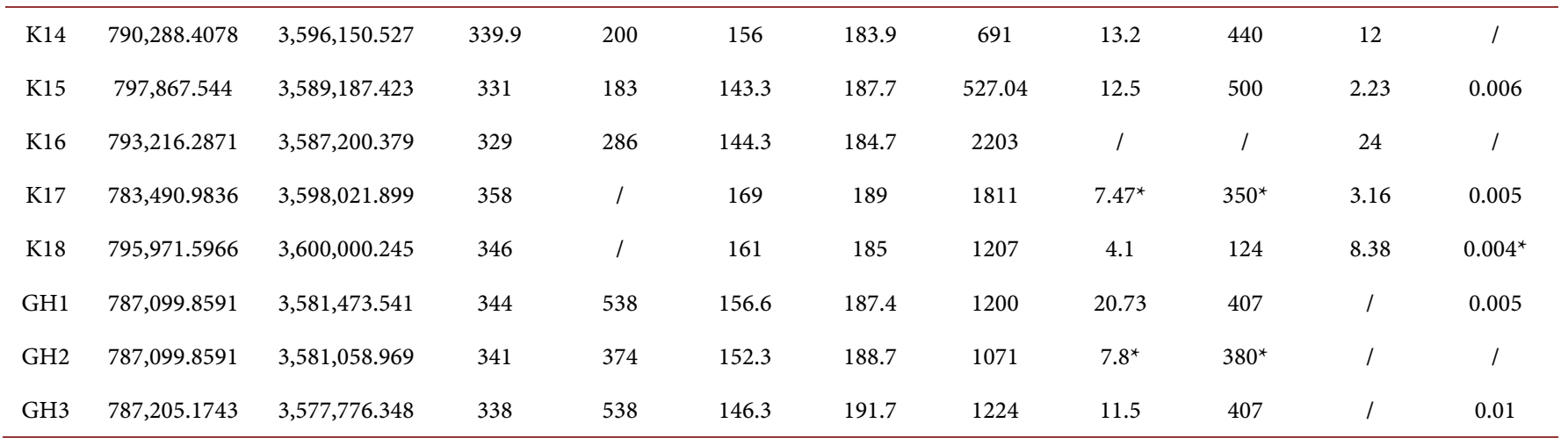

${ }^{\star}$ Interpolated values.

Table 3. Laboutka Classification for hydraulic parameters of aquifers [15].

\begin{tabular}{ccccc}
\hline Class & $\begin{array}{c}\text { Permeability } \\
\mathrm{m} / \text { day }\end{array}$ & $\begin{array}{c}\text { Transmissivity } \\
\mathrm{m}^{2} / \text { day }\end{array}$ & $\begin{array}{c}\text { Specific capacity } \\
\mathrm{m}^{3} / \text { day } / \mathrm{m}\end{array}$ & $\begin{array}{c}\text { Discharge } \\
\mathrm{m}^{3} / \text { day }\end{array}$ \\
\hline v. high & $>864$ & $>950$ & $>864$ & $>2160$ \\
high & $86.4-864$ & $95-950$ & $86.4-864$ & $432-2160$ \\
middle & $8.64-86.4$ & $9.5-95$ & $8.64-86.4$ & $432-43.2$ \\
low & $<8.64$ & $<9.5$ & $<8.64$ & $<43.2$ \\
\hline
\end{tabular}

and Abu Ghar with the extension of Fault trace (F3), whereas the permeability values decrease in area ESE Nukhaib town and its extensions within Habbariyia depression, whereas the transmissivity value decreases in the vicinity of Nukhaib, specifically in the East and Southeast direction. The groundwater of Um Erdhuma-Tayarat aquifer is controlled by unconfined conditions, where the amount of storativityranged from $10^{-3}$ to $5 \times 10^{-2}$ (Table 2) [16]-[18].

The results of storage coefficient show low variation in values originated to the same geostructural settings and rocks characteristics. The spatial distribution variation of storativity shows an increasing in storativity variation grade ranged between $3.7 \times 10^{-8}$ and $3.2 \times 10^{-5}$ per meter distance towards Habbariyia extensions, whereas storativity value decreases in the vicinity of Nukhaib in the south part and new Kasra in north portion.

The amount of well productivity from UmErdhuma-Tayarat aquifer ranged between $162 \mathrm{~m}^{3} /$ day and $2203 \mathrm{~m}^{3} /$ day. Depending on Laboutka classification [15], the wells within study area are classified within the wells of medium-very high productive.

The specific capacity of the water wells ranged between 1.8 and $21.1 \mathrm{liter} / \mathrm{sec} / \mathrm{m}$ ( Table 2) within wells depths ranged from 125 meters to 538 meters. The spatial distribution of specific capacity confirmed an increasing in variation grade ranged between 0.000003 and $0.0076 \mathrm{liter} / \mathrm{sec} / \mathrm{m}$ (depth) per meter distance towards wells of Kasra in high to very high category of specific capacity classification while it decreases to lowmedium category of specific capacity classification in the other part. 


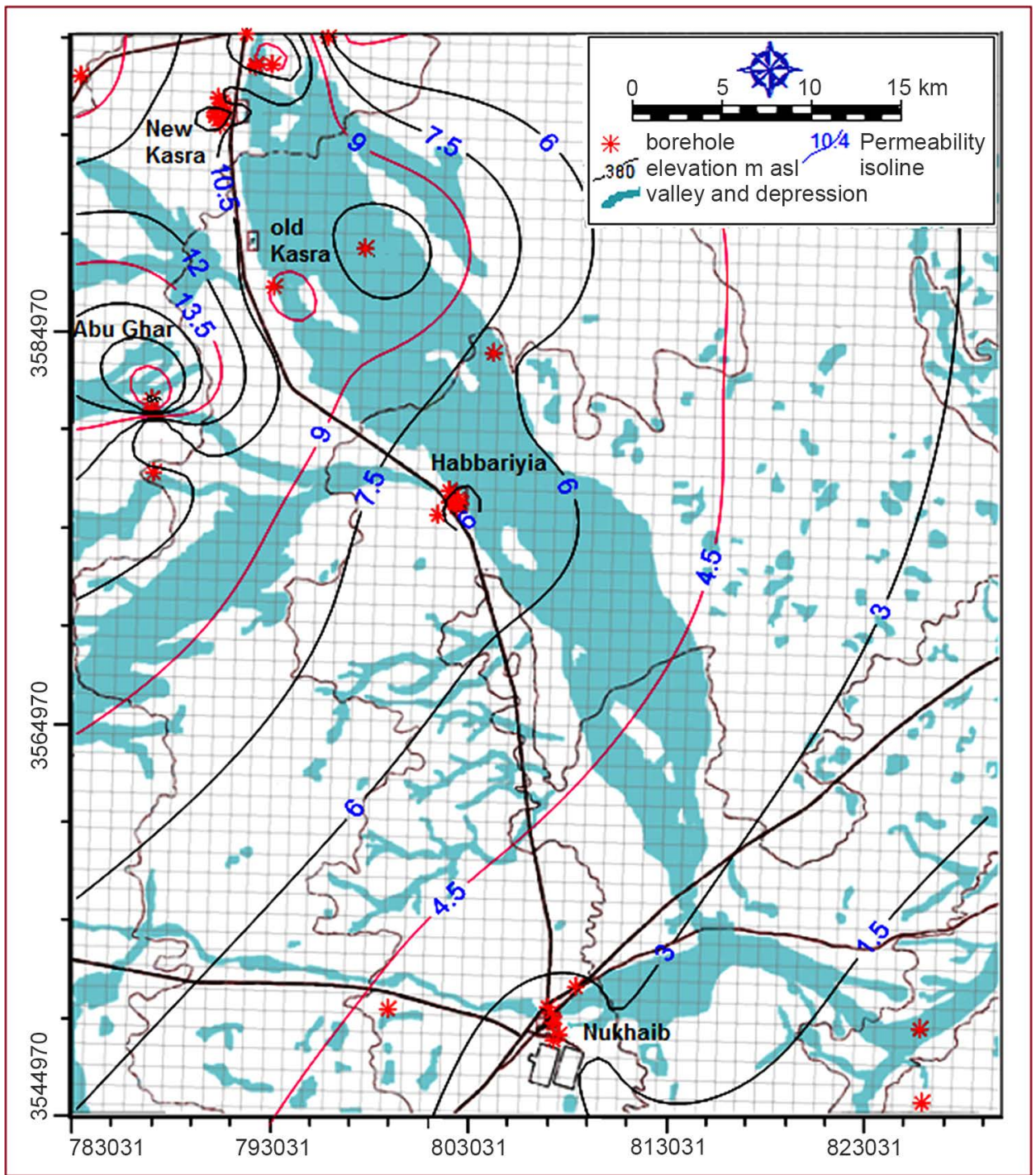

Figure 5. Spatial variation map of permeability.

The groundwater flow model is determined throughout observation of groundwater levels (Table 2), using Groundwater Contour Software. The main hydrogeologic phenomena that deduced from the groundwater flow model (Figure 6), supported by equations No.1 and No.2 are briefly discussed as follows "The groundwater within UmErdhuma-Tayarat aquifer moves from the west and southwest portions in the area existed west Nukhaib graben and also flows from the north portion in the area located northeast Nukhaib graben towards Habbariyia region and its suburbs area. This region represents a groundwater discharge zone due to intense exploitation and/or deep percolation throughout buried sinkholes and karst passages forming a boundary of captured zone. The groundwater flows under the effort of hydraulic gradient $(\delta \mathrm{h} / \delta \mathrm{l})$ ranged from 0.000011 (11 cm/10 kilometers) to 0.007 ( $7 \mathrm{~cm} / 10$ meters), rate of groundwater flux ranged between $0.00000012 \mathrm{~cm} /$ day and $0.0066 \mathrm{~cm} /$ day and rate of groundwater pore velocity ranged from $0.000024 \mathrm{~cm} /$ day to $6.6 \mathrm{~cm} /$ day". 


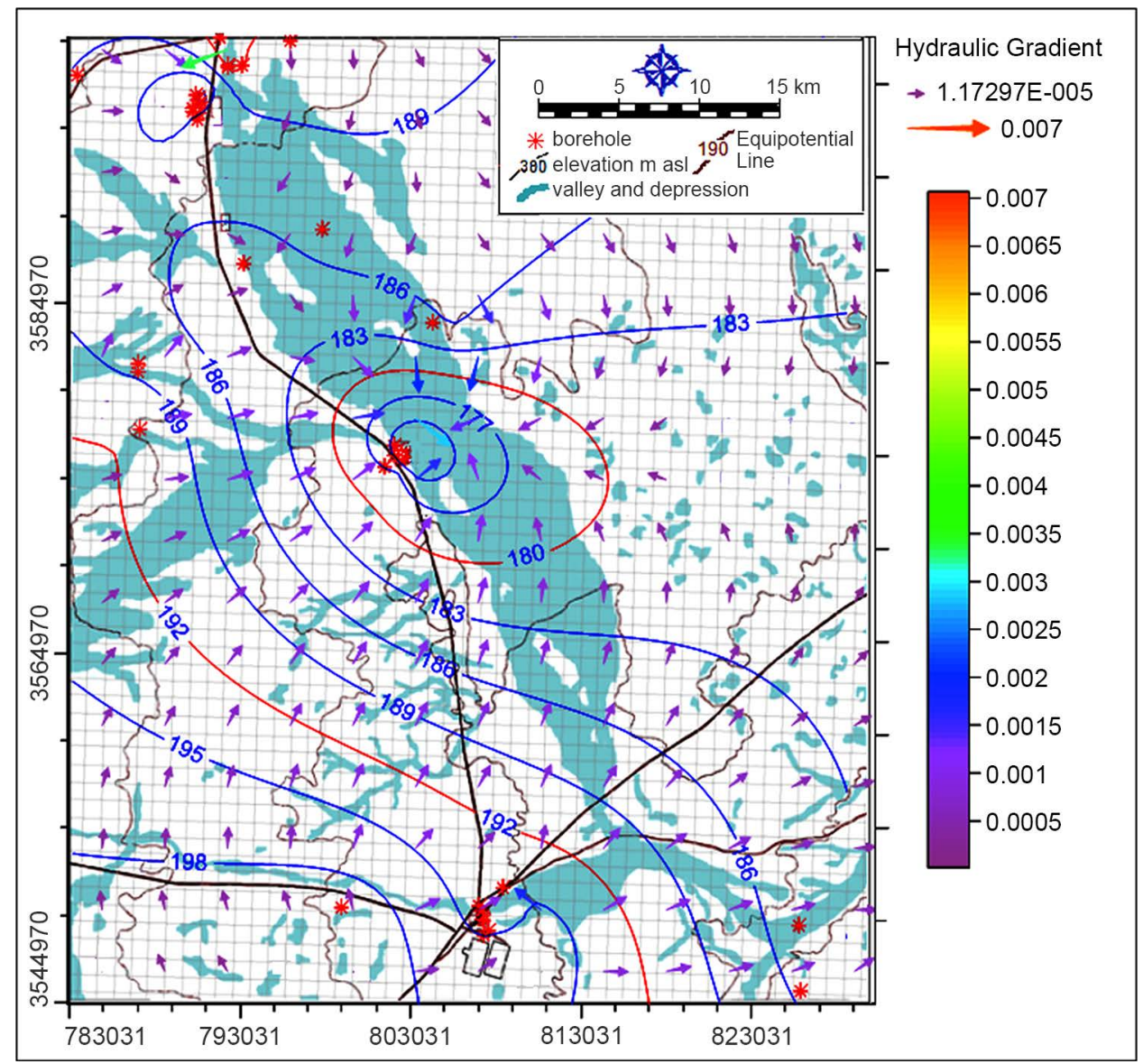

Figure 6. Groundwater flow model.

$$
\text { Groundwater Flux (V) = KI , [19] }
$$

where I: hydraulic gradient, K: permeability,

$$
\text { Groundwater pore velocity }(\mathrm{U})=\mathrm{V} / \mathrm{s},[20][21] \text {. }
$$

where V: groundwater Flux, s: specific yield or effective porosity,

\section{Materials and Methods}

The study was carried out based on the groundwater monitoring program in 24 wells within the scope of Habbariyia depression during 2013 water year. The coordinates are set by Garmin GPS. The groundwater levels measured by electrical sounder and rely on procedures in scientific references [22]-[25]. The processes of taking samples from wells were achieved according to the field procedures explained in the studies [26] [27]. All tools and bottles were washed with distilled water and then rinsed by sample water before packing to ensure the elimination of pollutants [28] [29].

Groundwater $\mathrm{pH}$ and electrical conductivity are measured after taking samples using calibrated EC-pH meters with standard solutions. Groundwater samples were analyzed in Soil and Water Laboratory (Centre of the desert studies). Field measurements and analyses data base comprise total dissolve solids (TDS), total Hardness $\left(\mathrm{H}_{\mathrm{T}}\right)$ and major 
ions were performed during same period of monitoring (June 2013). The chemical analyses of anions, cations, total dissolved solids (TDS) and total Hardness and field measurements are listed in Table 4.

Chemical composition reliability was checked using the charge balance method [21]. Groundwater quality and the hydrogeochemical mechanisms that affect the origin of groundwater and facies [30] are statistically assessed using the application of Curve expert v1.3 software. The groundwaters of the aquifers are classified based on hydrochemical ratios and saturation indices. Saturation indices (Table 5) of some common

Table 4. Field measurements and Chemical analyses of the groundwater within UmErdhuma-Tayarat aquifer.

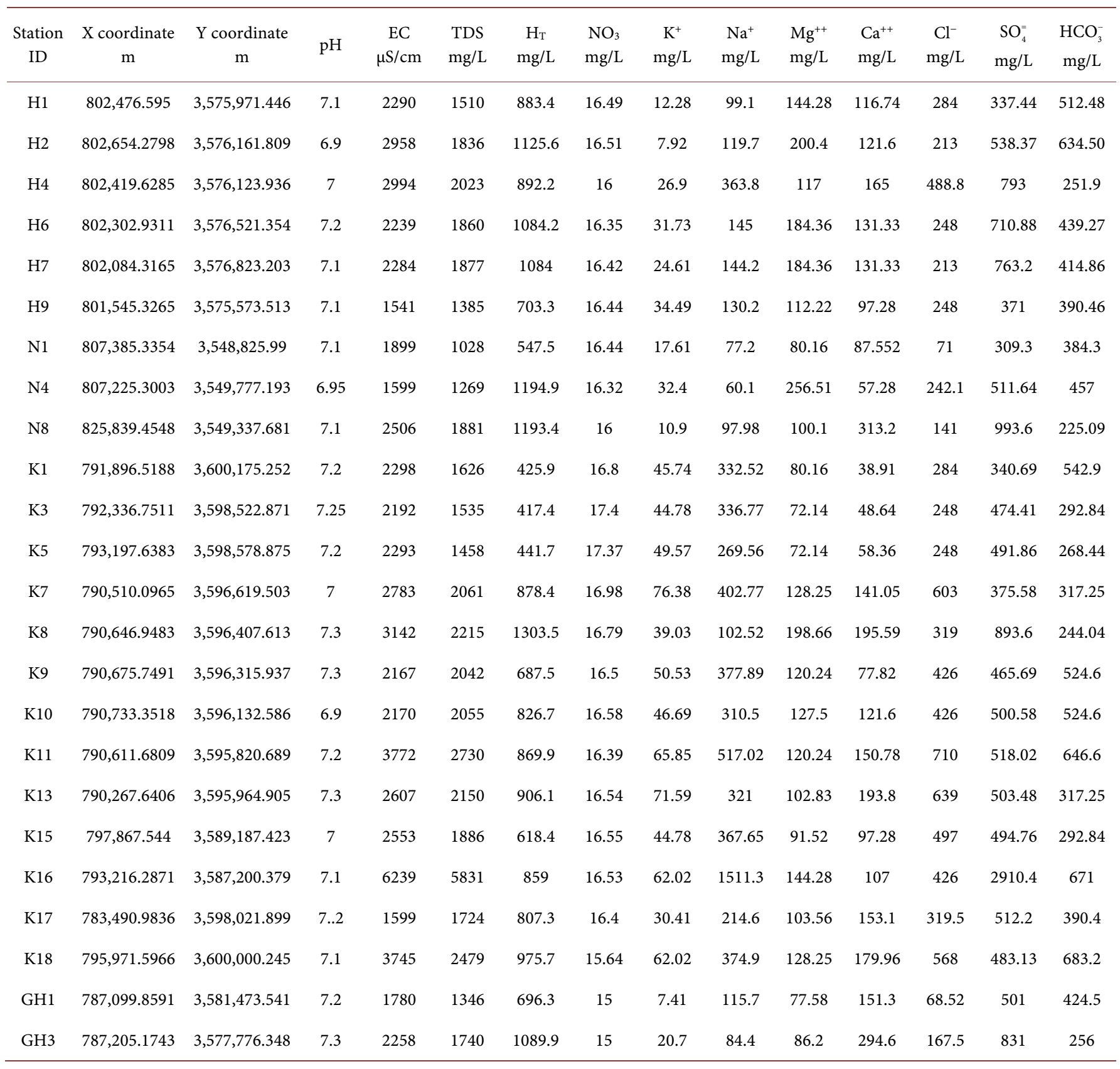


Table 5. Saturation and Hydrochemical Indicesof the groundwater within UmErdhuma-Tayarat aquifer.

\begin{tabular}{|c|c|c|c|c|c|c|c|c|c|c|c|c|c|}
\hline \multirow[b]{2}{*}{ Well No. } & \multicolumn{7}{|c|}{ Saturation Indices } & \multicolumn{6}{|c|}{ Hydrochemical Indices } \\
\hline & $\begin{array}{c}\text { SI } \\
\text { Calcite }\end{array}$ & $\begin{array}{c}\text { SI } \\
\text { Aragonite }\end{array}$ & $\begin{array}{c}\text { SI } \\
\text { Dolomite }\end{array}$ & $\begin{array}{c}\text { SI } \\
\text { Gypsum }\end{array}$ & $\begin{array}{c}\text { SI } \\
\text { Anhydrite }\end{array}$ & $\begin{array}{c}\text { SI } \\
\text { Halite }\end{array}$ & $\begin{array}{c}\text { SI } \\
\text { Sylvite }\end{array}$ & $(\mathrm{Na}+\mathrm{K}) / \mathrm{Cl}$ & $\mathrm{HCO}_{3} / \mathrm{Cl}$ & $\mathrm{SO}_{4} / \mathrm{Cl}$ & $\mathrm{Ca} / \mathrm{Mg}$ & CAI1 & CAI2 \\
\hline $\mathrm{H} 1$ & 0.11 & -0.04 & 0.65 & -1.19 & -1.5 & -6.18 & -6.66 & 0.58 & 1.05 & 0.88 & 0.49 & 0.42 & 0.22 \\
\hline $\mathrm{H} 2$ & 0.17 & 0.03 & 0.89 & -1.05 & -1.35 & -6.23 & -6.98 & 0.9 & 1.73 & 1.87 & 0.37 & 0.1 & 0.03 \\
\hline H6 & 0.03 & -0.11 & 0.54 & -0.9 & -1.2 & -6.09 & -6.31 & 1.01 & 1.03 & 2.11 & 0.43 & -0.01 & -0.005 \\
\hline $\mathrm{H} 7$ & 0.00 & -0.14 & 0.48 & -0.87 & -1.17 & -6.16 & -6.49 & 1.15 & 1.13 & 2.65 & 0.43 & -0.15 & -0.04 \\
\hline $\mathrm{H} 9$ & -0.07 & -0.21 & 0.26 & -1.24 & -1.55 & -6.11 & -6.25 & 0.94 & 0.91 & 1.1 & 0.52 & 0.06 & 0.03 \\
\hline N8 & 0.09 & -0.06 & 0.00 & -0.4 & -0.7 & -6.51 & -7.02 & 1.14 & 0.93 & 5.21 & 1.89 & -0.14 & -0.02 \\
\hline K1 & -0.16 & -0.31 & 0.15 & -1.43 & -1.74 & -5.65 & -6.08 & 1.95 & 1.11 & 0.88 & 0.29 & -0.95 & -0.47 \\
\hline K3 & -0.51 & -0.66 & -0.53 & -1.35 & -1.66 & -5.78 & -6.14 & 1.9 & 0.68 & 1.41 & 0.41 & -0.9 & -0.43 \\
\hline K5 & -0.48 & -0.62 & -0.53 & -1.27 & -1.57 & -5.8 & -6.1 & 1.86 & 0.63 & 1.47 & 0.49 & -0.86 & -0.4 \\
\hline K7 & -0.04 & -0.19 & 0.22 & -1.09 & -1.39 & -5.48 & -5.54 & 0.73 & 0.3 & 1.12 & 0.67 & 0.26 & 0.34 \\
\hline K8 & -0.08 & -0.22 & 0.18 & -0.67 & -0.97 & -6.13 & -6.12 & 0.61 & 0.44 & 2.07 & 0.59 & 0.39 & 0.15 \\
\hline K15 & -0.24 & -0.38 & -0.17 & -1.1 & -1.41 & -5.38 & -5.86 & 1.22 & 0.34 & 0.73 & 0.64 & -0.22 & -0.21 \\
\hline K16 & -0.13 & -0.28 & 0.17 & -0.68 & -0.98 & -4.92 & -5.88 & 5.6 & 0.91 & 5.05 & 0.45 & -4.6 & -0.77 \\
\hline K17 & 0.08 & -0.07 & 0.32 & -0.91 & -1.21 & -5.80 & -6.21 & 1.12 & 0.71 & 1.18 & 0.9 & -0.12 & -0.06 \\
\hline K18 & 0.35 & 0.21 & 0.9 & -0.94 & -1.24 & -5.33 & -5.67 & 1.11 & 0.7 & 0.63 & 0.85 & -0.11 & -0.09 \\
\hline GH1 & 0.13 & -0.01 & 0.31 & -0.87 & -1.17 & -6.72 & -7.48 & 2.7 & 3.6 & 5.4 & 1.18 & -1.7 & -0.18 \\
\hline GH3 & 0.14 & 0.0 & 0.07 & -0.47 & -0.77 & -6.49 & -6.67 & 0.89 & 0.89 & 3.67 & 2.07 & 0.11 & 0.02 \\
\hline
\end{tabular}

$\mathrm{CAI} 1=[\mathrm{Cl}-(\mathrm{Na}+\mathrm{K})] / \mathrm{Cl} ; \mathrm{CAI} 2=[\mathrm{Cl}-(\mathrm{Na}+\mathrm{K})] /\left[\mathrm{SO}_{4}+\mathrm{HCO}_{3}\right]$.

minerals were calculated using the program PHREEQC [31]. The interpretations of hydrochemical phenomena are done based on Piper trilinear, Durov plots and spatial analysis maps of hydrochemical variables using Groundwater Contour software. Also, Rockwork 14 is used in the preparation of hydrogeo-structural models, geologic map, and sections. 


\section{Results and Discussion}

\subsection{Hydrochemical Characterization}

The measured electrical conductivity ranged between 1541 and $6239 \mu \mathrm{Scm}^{-1}$ of the groundwater within UmErdhuma-Tayarat aquifer (Table 4) indicates significant variation of EC $\left(\mu \mathrm{Scm}^{-1}\right)$ between minimum and maximum value with spatial space variation ranging from 0.001 to $1.08 \mu \mathrm{Scm}^{-1} /$ meter. The variation reflected the influences of shallow and deep sources and geochemical process. The groundwater of the aquifer within study region has $\mathrm{pH}$ values ranging from 6.9 to 7.3 decreased in the replenishment scope of groundwater within Habbariyia depression. Therefore the groundwater classified as neutral to slightly alkaline water with low spatial variation of $\mathrm{pH}$ ranged between 0.0000001 and $0.0002 \mathrm{pH} /$ meter. The total Hardness of the groundwater ranged from 417.4 to $1303.5 \mathrm{mg} / \mathrm{l}$, classified as very hard water according to $\mathrm{H}_{\mathrm{T}}$ classification [29], the variation in total hardness values within the aquifer is due to fluctuation in calcium and magnesium concentrations due to the process of eutrophication caused by solvent ions and/or cation exchange reactions. The results of the groundwater ability for corrosion and salt incrustation based on total Hardness indicate a predominant distinction for salt incrustation and high capacity for corrosion.

The chloride concentration in the groundwater varies between 68.5 and $710 \mathrm{mg} / \mathrm{L}$. The atmospheric precipitation, dissolution of salt deposits and weathering of halite and evaporite are considered as a major lithogenic source of chloride in the groundwater, while the anthropogenic sources are of very low effectiveness due to deep groundwater occurrence in a desert region. Distribution map of chloride ion (Figure 7), shows a decrease of concentration in a dilution grade of 0.0001 to $0.266 \mathrm{mg} / \mathrm{liter} / \mathrm{m}$ towards central portion corresponding with the flow direction. The dilution in chloride concentration may be attributed to the local groundwater replenishment within Habbariyia depression.

The Concentration of sulphate ion in the groundwater of aquifer varies from 337.44 to $2910.4 \mathrm{mg} / \mathrm{L}$ with spatial space variation of $\mathrm{SO}_{4}$ ranged between 0.0002 and 0.387 $\mathrm{mg} / \mathrm{L} / \mathrm{meter}$ within study region. Sulphate concentration in natural water is usually found between 2 and $80 \mathrm{mg} / \mathrm{L}$. The concentration of $\mathrm{SO}_{4}$ is attributed to the weathering of rocks forming minerals such as gypsum and anhydrite (UmErdhuma component media). Saturated indices of gypsum and anhydrite with negative values $(\mathrm{SI}<0)$ in $\mathrm{Ta}$ ble 5 show that the groundwater is still active to leach sulphate ions from gypsum and anhydrite minerals phase. The concentration of $\mathrm{HCO}_{3}$ ion in the groundwater samples of aquifervaries from 225.09 to $683.2 \mathrm{mg} / \mathrm{L}$. The higher proportions of bicarbonate dominated by alkaline earths $\mathrm{Ca}+\mathrm{Mg}$ in relation to other anions may indicate weathering of limestone and dolomite. All bicarbonate water types are a result of hydrochemi-

cal processes acting between water and aquifer matrix, while the variation reflects the effectiveness of groundwater flow path.

The concentration of calcium ion in the groundwater of aquifer ranged between 38.91 and $313.2 \mathrm{mg} / \mathrm{L}$ with regional space variation of about 0.00001 to $0.085 \mathrm{mg} / \mathrm{L} / \mathrm{meter}$, decreased in the scope of Habbariyia depression. The magnesium concentration of 


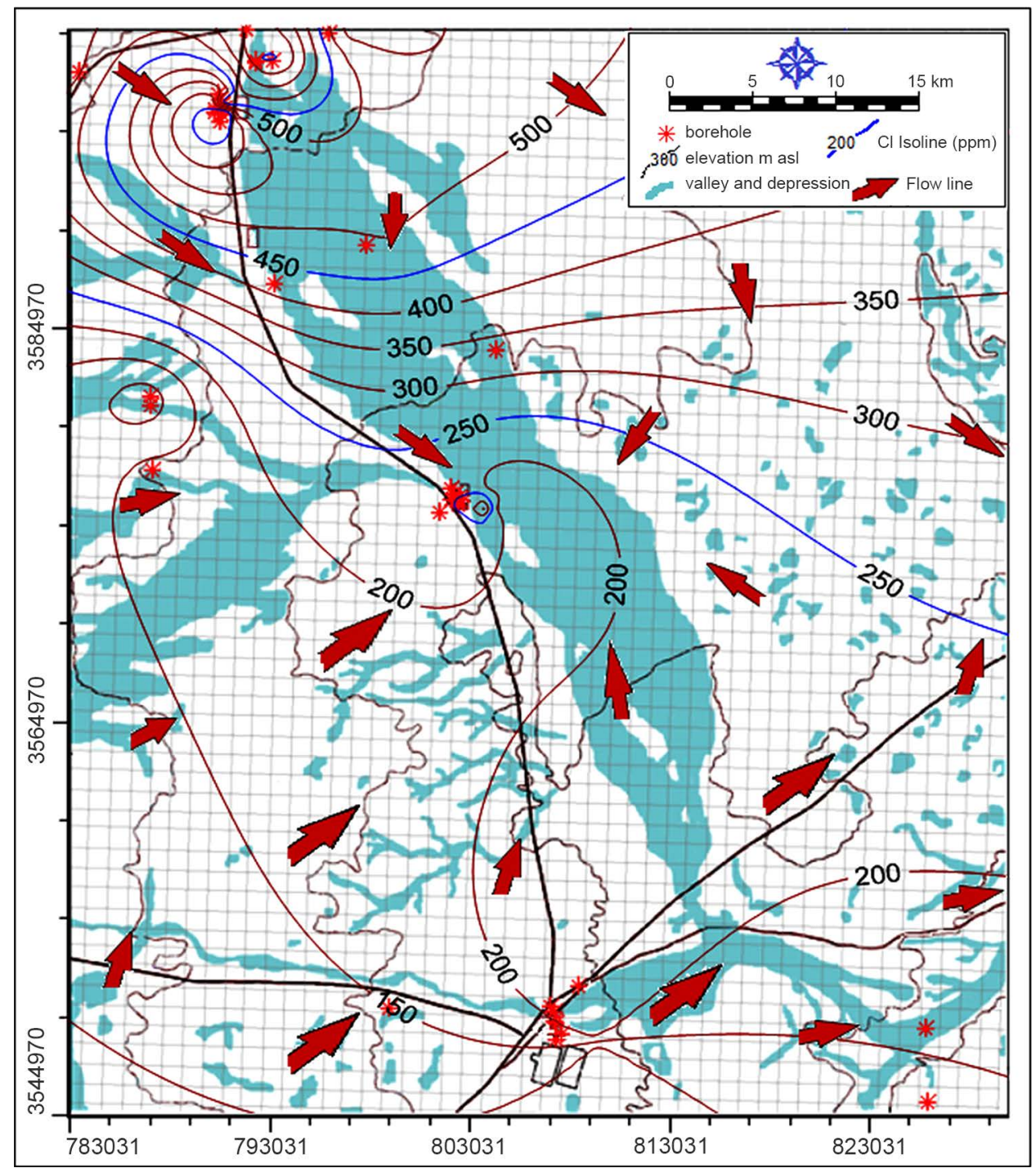

Figure 7. Spatial distribution map of chloride ion compiled with groundwater flow.

groundwater within study region varies from 72.14 to $256.51 \mathrm{mg} / \mathrm{L}$, with regional spatial variation ranged between 0.00001 and $0.13 \mathrm{mg} / \mathrm{L} / \mathrm{meter}$, enriched with the groundwater evolution and flow direction. These concentrations denoting supply of magnesium and calcium from weathering of carbonate and evaporite rocks (lime stone, dolomite and gypsum), which form aquifers sediment. The concentration of sodium and potassium ions in the groundwater varies between 60.1 and $1511.3 \mathrm{mg} / \mathrm{L}$ and from 7.41 to $76.38 \mathrm{mg} / \mathrm{L}$ with spatial variation ranged between 0.00005 and $0.155 \mathrm{mg} / \mathrm{L} / \mathrm{meter}$, and between 0.000001 and $0.025 \mathrm{mg} / \mathrm{L} /$ meter, respectively. The presence of $\mathrm{Na}$ and $\mathrm{K}$ ions in the groundwater may be attributed to the dissolution of these ions from evaporite minerals of aquifers media. Saturated indices of halite and sylvite with negative values $(\mathrm{SI}<0)$ in Table 4 indicate a capability of leach process still active for sodium and potassium ions from halite and sylvite minerals phase.

The Total Dissolve Solids of the groundwater ranged from 1028 to $2730 \mathrm{mg} / \mathrm{L}$. 
Therefore the groundwater classified as slightly saline water according to TDS classification [32] [33]. Distribution map of TDS (Figure 8), shows increase of concentration in an leaching grade of 0.0008 to $0.62 \mathrm{mg} / \mathrm{liter} / \mathrm{m}$ to the scope of Habbariyia village corresponding with the flow direction.

\subsection{Hydrochemical Facies and Classification}

The chemical characteristics of the groundwater within UmErdhuma-Tayarat aquifer have been determined by the application of hydrochemical facies, which reflects the effect of chemical processes upon media of water bearing horizons. The groundwater facies in the aquifer reveals the majority percent of water samples of;

- Sulphate Group (63\% of groundwater samples) including Mg-Sulphate Family forming $29 \%$ of groundwater samples, Na-Sulphate Family forming $21 \%$ of groundwater samples, and Ca-Sulphate Family forming 13\% of groundwater samples.

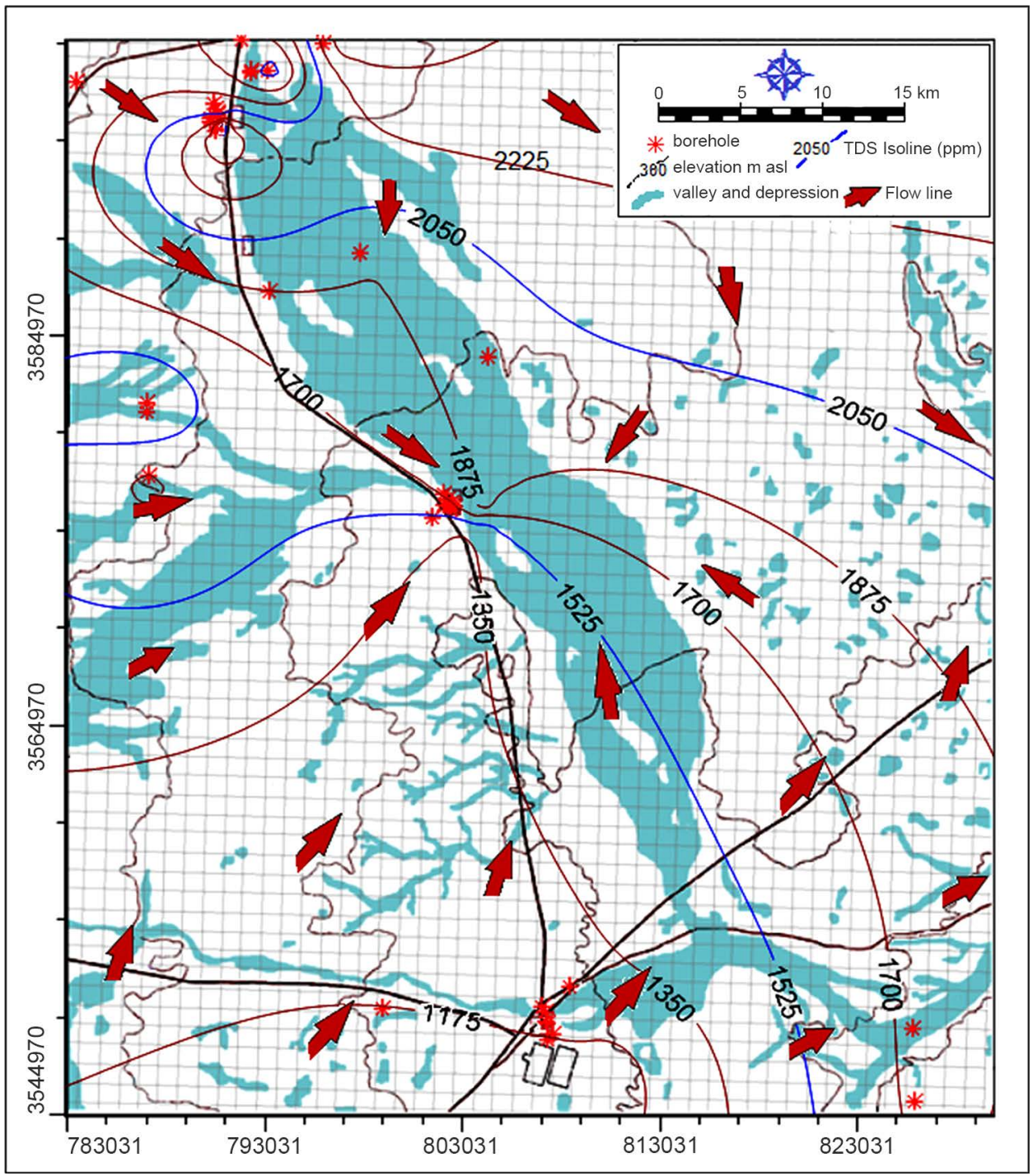

Figure 8. Spatial distribution map of TDS compiled with groundwater flow. 
- Chloride group (29\% of groundwater samples) as Na-chloride Family.

- Bicarbonate group (8\% of groundwater samples) as Mg-Bicarbonate forming $4 \%$ of groundwater samples and Na-bicarbonate forming $4 \%$ of groundwater samples.

All such sulphate and bicarbonate types are the result of hydrochemical processes acting aquifer matrix such as leaching and dissolution of evaporate and carbonate rocks, which are commonly encountered within aquifer media. The variation in ions concentration reflects the effectiveness of groundwater flow path [34].

Some water types characterize salty groundwater with $\mathrm{Na}-\mathrm{Cl}$ dominant typeprobably derived from the dissolution of disseminated halite in fine-grained sediments. While water of $\mathrm{Na}-\mathrm{Mg} ; \mathrm{SO}_{4}$-Cl dominant type representing a mixed water type.

Piper trilinear diagramwas applicated for the purpose of characterizing groundwater types of the aquifer, using hydrochemical data (meq \%).

Figure 9 shows that the plotted points of the groundwater within Habbariyia, Nukhaib and Abu Ghar regions mainly indicating by none of the cation pair $(\mathrm{Na}+\mathrm{K})$ or anion pair $\left(\mathrm{CO}_{3}+\mathrm{HCO}_{3}\right)$ exceed $50 \%$ \{ions of alkaline earths $(\mathrm{Ca}+\mathrm{Mg})$ exceeds alkalies $(\mathrm{Na}+\mathrm{K})$ and ions of strong acids $\left(\mathrm{SO}_{4}+\mathrm{Cl}\right)$ exceeds ions of weak acids $\left(\mathrm{CO}_{3}+\right.$ $\left.\mathrm{HCO}_{3}\right)$ \} followed by ions of non-carbonate hardness (secondary salinity) exceeds $50 \%$ represented by $\mathrm{Ca}-\mathrm{Mg}-\mathrm{Cl}-\mathrm{SO}_{4}$ water type, then by Non-carbonate alkali ions (primary salinity) exceeds $50 \%$ defined by $\mathrm{Na}-\mathrm{Cl}$ groundwater type within Kasra region.

Figure 10 represents the Gibb's ideas as both plots of total dissolved solids (TDS) versus $(\mathrm{Na}+\mathrm{K}) /(\mathrm{Na}+\mathrm{K}+\mathrm{Ca})$ and $\mathrm{Cl} /\left(\mathrm{Cl}+\mathrm{HCO}_{3}\right)$ weight ratios where the concentration of ions is in meq/l. These diagrams are widely used in order to have an explanation of the general chemistry of water [35].

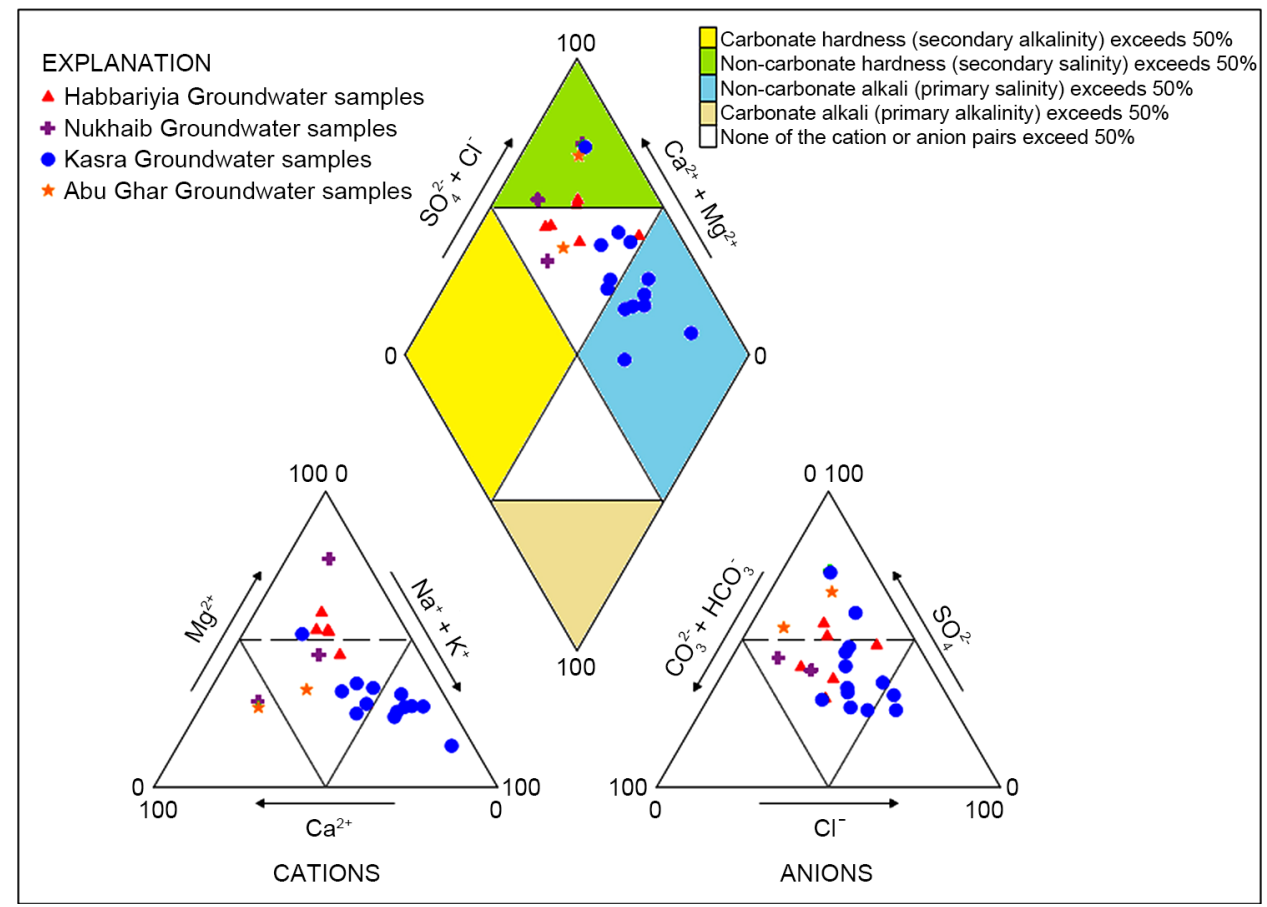

Figure 9. Groundwater quality of UmErdhuma-Tayarat aquifer plotted on Piper diagram. 


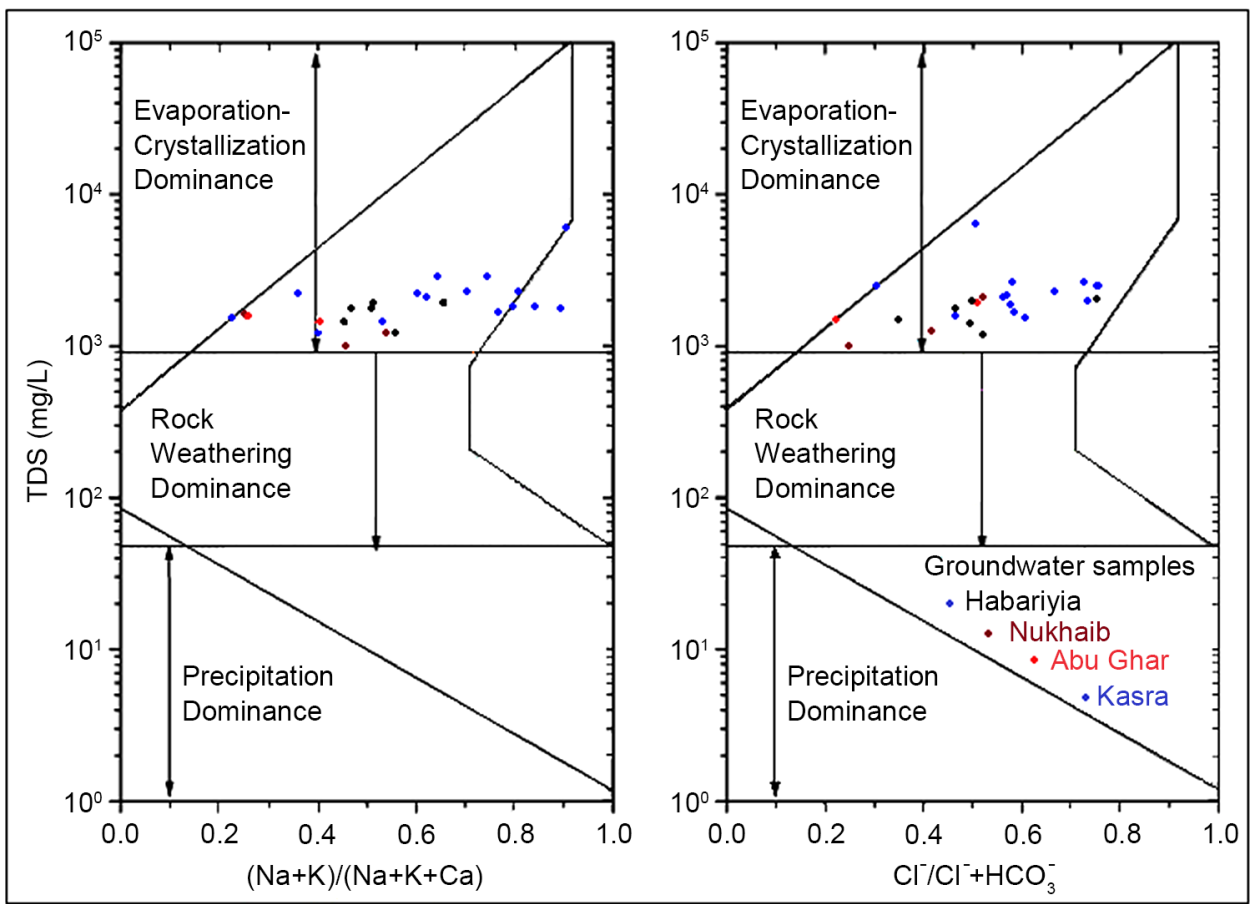

Figure 10. Groundwater quality of UmErdhuma-Tayarat aquifer plotted on Gibbs diagram.

Accordingly, it is found that the groundwater of UmErdhuma-Tayarat aquifer plotted within the evaporation category, which suggests that the evaporation process is mainly controls the major ion chemistry of groundwater, where the study region experiences dry and semiarid climatic condition so that evaporation may also contribute in water chemistry that affects the groundwater quality.

\subsection{Geochemical Evolution of Groundwater}

Presentation of groundwater chemistry on Durov diagram is used to determine the geochemical evolution of groundwater within UmErdhuma-Tayarat aquifer. Geochemical evolution proceeds as indicated by the arrow on the Durov diagram, towards the $\mathrm{Na}-\mathrm{Cl}$ type. Since the groundwater of aquifer subject to meteoric origin, the dissolution and ion exchange process assumes great significance in the salinized zones and is a very important factor regulating ions concentrations in the groundwater. The results of plotted chemical data on Durov's diagram is used to identify the geochemical evolution of groundwaters where the groundwater are initially recharged by $\mathrm{Ca}-\mathrm{HCO}_{3}$ water (rain water) and undergo water-rock interactions (dissolution) and mixing with pre-existing groundwater in karstified dolomitic limestone that may be of saline nature. This leads to the evolution of $\mathrm{Mg}-\mathrm{SO}_{4}$ and $\mathrm{Na}_{2} \mathrm{SO}_{4}$ water types and finally reaches an advanced state of geochemical evolution, which is represented by the $\mathrm{Na}-\mathrm{Cl}$ type. Figure 11 shows that the groundwater are mainly plotted in $\mathrm{Mg}_{-} \mathrm{SO}_{4}$ field No.5 represented by $\mathrm{Ca}-\mathrm{Mg}-\mathrm{HCO}_{3}-\mathrm{SO}_{4}$ water type, indicating mixed water type that affected by dissolution process is possibly evolved from $\mathrm{Ca}-\mathrm{HCO}_{3}$ recharge water, affected by ion exchange process (presence of $\mathrm{Na}_{2} \mathrm{SO}_{4}$ water type in field No. 6). Limited reverse ion exchange 


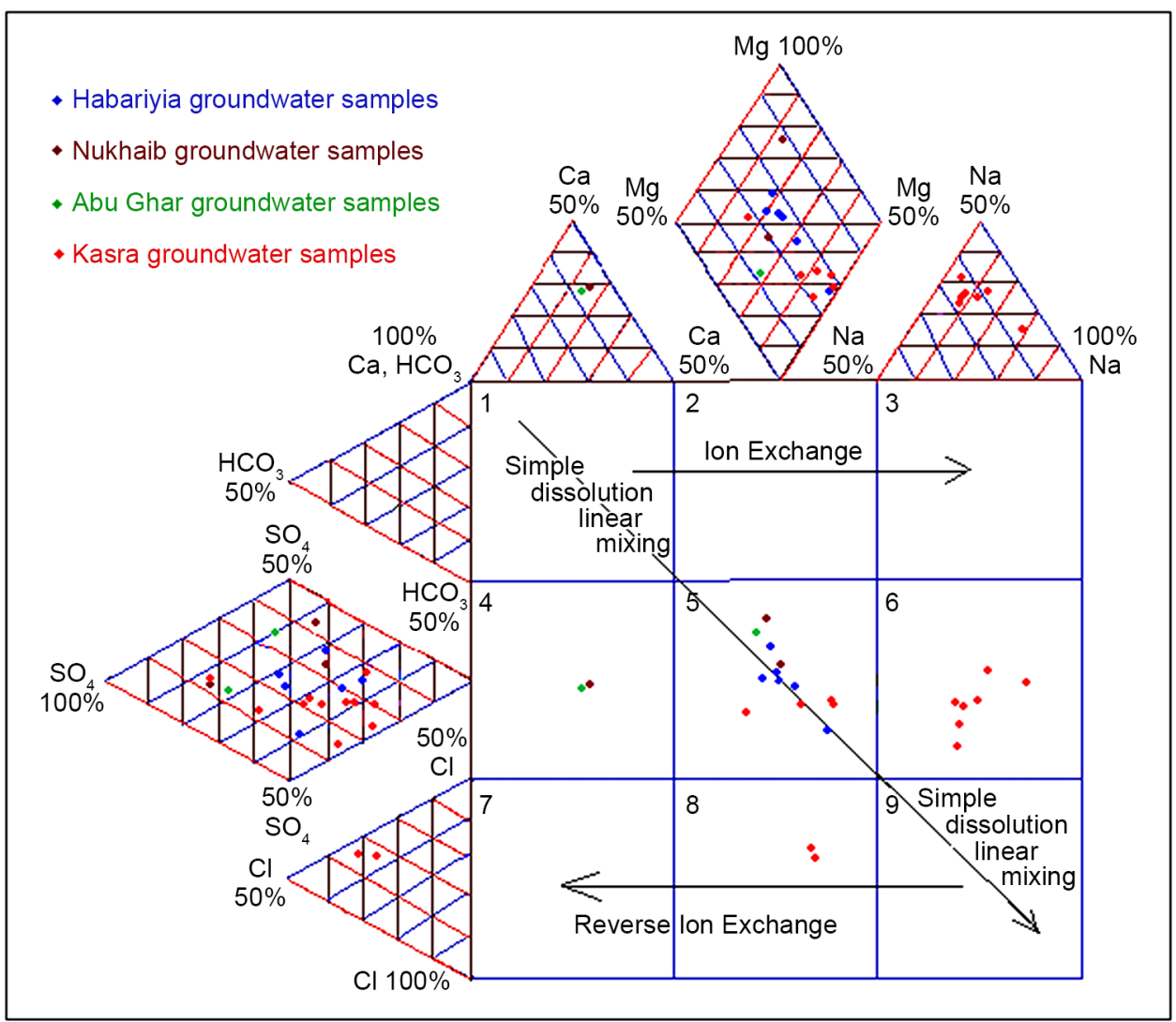

Figure 11. Plotting of groundwater analyses of UmErdhuma-Tayarat aquifer on Durov diagram.

has been noticed in field No. 4 and 8 (presence of $\mathrm{CaSO}_{4}$ and $\mathrm{MgCl}_{2}$ water type respectively).

\subsection{Impact of Hydrochemistry on Geochemical Evolution of Groundwater}

The evolution of geochemical properties of groundwater depends on the origin of water recharge (meteoric water and/or fossil water) and on the subsurface geochemical processes within the aquifer system. Theimpacts of hydrochemistry on the groundwater evolution were examined through metasomatic changes of anions, ion exchange process, leaching, and dissolution of minerals, evaporation, and oxidation reduction.

\subsubsection{Metasomatic Changes}

The anions of groundwater components showed change when water comes in contact with rocks. The changes increased with depth and/or distance from recharge to discharge zone along the flow path. The majority of the groundwater types of UmErdhuma-Tayarat aquifer ( $62.5 \%$ of the total samples) belongs to intermediate advanced grade of metasomatic sequence are $\mathrm{SO}_{4}>\mathrm{HCO}_{3}>\mathrm{Cl}(25 \%)$ and $\mathrm{SO}_{4}>\mathrm{Cl}>\mathrm{HCO}_{3}$ $(37.5 \%)$. This could be attributed to the subsurface leaching and mixing actions throughout groundwater percolation.

The groundwater types (29\% of the total samples) belongs to the more advanced 
grade of metasomatic sequence are $\mathrm{Cl}>\mathrm{SO}_{4}>\mathrm{HCO}_{3}(25 \%)$ and $\mathrm{Cl}>\mathrm{HCO}_{3}>\mathrm{SO}_{4}(4 \%)$. This is due to mixing action of various water types along groundwater flow direction. The groundwater types ( $8.5 \%$ of the total samples) belongs to the less advanced grade of metasomatic sequence are $\mathrm{HCO}_{3}>\mathrm{Cl}>\mathrm{SO}_{4}$. This could be attributed to the leaching of land surface due to rain and runoff waters that passed through hydrographic basins.

\subsubsection{Solution-Mineral Equilibria (Saturation Indices)}

The saturation index describes the deviation of water from equilibrium with respect to dissolved minerals quantitatively. Saturation Index (SI) and Mineral equilibrium calculations are used in predicting and estimating mineral reactivity in the groundwater system [36]. It is possible to estimate the chemical reactivity (water-rocks interaction) from the chemical analyses of the groundwater without collecting the solid phase samples and analyzing mineralogy, using saturation indices (SI) [37]. Saturation index is defined as the logarithm of the ratio of ion activity product (IAP) to the mineral equilibrium constant at a given temperature and expressed as: $\mathrm{SI}=\log (\mathrm{IAP} / \mathrm{Ksp})$ where IAP is the ion activity product and Ksp is the solubility product of the mineral. The saturation index values of soluble minerals in the groundwaters are calculated by PHREEQC software [31]. A negative saturation index $(\mathrm{SI}<0)$ indicates under saturation conditions and dissolution of mineral phase. Such a value could reflect the character of water from a formation with insufficient amount of mineral for solution or short residence time. Appositive index ( $\mathrm{SI}>0$ ) indicates that the water is supersaturated with respect to the particular mineral phase. Therefore incapable of dissolving more mineral under same physico-chemical condition, the mineral phase in equilibrium may precipitate. A neutral SI $(\mathrm{SI}=0)$ is in equilibrium state with the particular mineral phase.

The calculated saturation index values of calcite (SIcal), aragonite (SIara), dolomite (SIdol), gypsum (SIgyp), anhydrite (SIanh), halite (SIhal) and sylvite (SIsyl) (Table 5), demonstrate that nearly all groundwater samples of UmErdhuma-Tayarat aquifer are slightly saturated with respect to dolomite, slightly under saturated with respect to aragonite. Fifty percent of groundwater samples are slightly saturated and the other half is under saturated with respect to calcite. All groundwater samples are slightly under saturated with respect to gypsum/anhydrite and moderately under saturated with respect to halite/sylvite. The saturation of carbonate phases may influenced the groundwater composition and leads to the precipitation of calcium as $\mathrm{Ca}$ and/or $\mathrm{Ca}-\mathrm{Mg}$ carbonate under suitable physico-chemical conditions. This process explains the presence of a mixture of calcite and/or dolomite in the subsurface stratigraphic profile of the study area. The dissolution of carbonate minerals controls the carbonate equilibria and causing saturation with respect to dolomite and calcite according to the following reactions:

$$
\begin{gathered}
\mathrm{Ca}^{2}+2 \mathrm{HCO}_{3} \rightarrow \mathrm{CaCO}_{3}+\mathrm{CO}_{2}+\mathrm{H}_{2} \mathrm{O} \\
\mathrm{Ca}^{2}+\mathrm{Mg}^{2}+4 \mathrm{HCO}_{3} \rightarrow \mathrm{CaMg}\left(\mathrm{CO}_{3}\right)_{2}+2 \mathrm{CO}_{2}+2 \mathrm{H}_{2} \mathrm{O}
\end{gathered}
$$

The under saturation of gypsum/anhydrite and halite/sylvite suggests low dissolution mechanisms of sulphate and chloride minerals phases happened in the host aquifers (insufficient amount of minerals for solution or short residence time). This leads to 
deduce that the evolution of sulphate water types are not reach the advanced state of geochemical evolution, means the groundwaters existed within the transition zone associated with local replenishment zones.

\subsubsection{Reduction-0xidation Process}

Oxidation reactions usually take place in the soil moisture zone near the atmosphere, where $\mathrm{O}_{2}$ is readily available, whereas the sulfate-reducing bacteria controls the reduction oxidation process (Redoxpotential) under the anaerobic conditions. In the study region, sulphate ions are originated to the dissolution of gypsum forming UmErdhuma rocks. The amount of $\mathrm{SO}_{4} / \mathrm{Cl}$ ratio (Table 5) in the groundwater of UmErdhumaTayarat aquifer is more than that in the oil field reduction water (equal to 0.015) [33], this ratio indicates no sulfate reduction process occurs within aquifer.

\subsubsection{Evaporation}

In general, the evaporation process causes an increase in concentrations of all species in water. $\mathrm{Na} / \mathrm{Cl}$ ratio can be used to identify the evaporation process in groundwater. Evaporation will increase the concentration of total dissolved solids in groundwater, and the $\mathrm{Na} / \mathrm{Cl}$ ratio remains the same, and it is one of the good indicative factors of evaporation. If evaporation is the dominant process, $\mathrm{Na} / \mathrm{Cl}$ ratio should be constant when TDS rises [38]. The TDS vs. $\mathrm{Na} / \mathrm{Cl}$ scatter diagram of the groundwater within UmErdhuma-Tayarat aquifer (Figure 12) shows that the trend line is fluctuated represented by 3rd degree Polynomial Fit:

$$
(\mathrm{Na}+\mathrm{K}) / \mathrm{Cl}=\mathrm{a}+\mathrm{b}(\mathrm{TDS})+\mathrm{c}(\mathrm{TDS}) \wedge 2+\mathrm{d}(\mathrm{TDS}) \wedge 3,
$$

and $\mathrm{Na} / \mathrm{Cl}$ ratio decreases with increasing salinity (TDS) till $3000 \mathrm{mg} / \mathrm{L}$, which seems to be removal of sodium by ion exchange reaction, then increases with the increase of TDS from $3000 \mathrm{mg} / \mathrm{L}$ to $5800 \mathrm{mg} / \mathrm{L}$, which seems to be received sodium by reverse ion exchange reaction (indicated by Durov plot). This observation indicates that evaporation

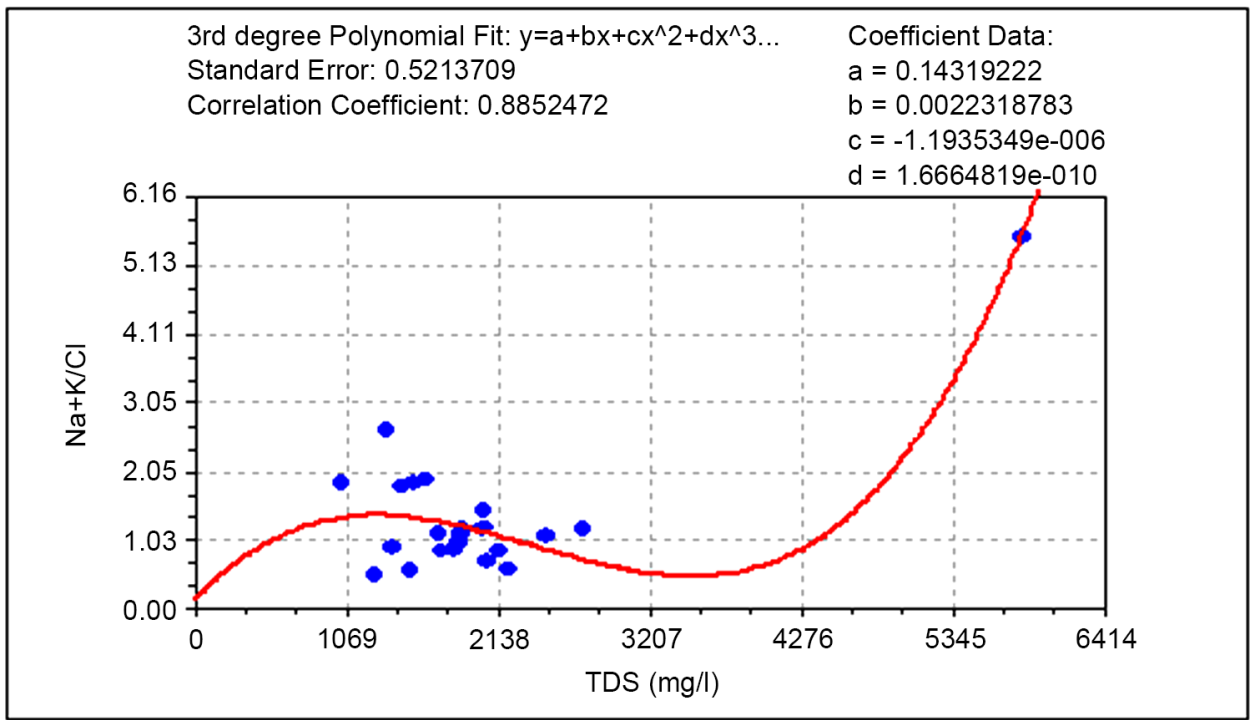

Figure 12. TDS vs. $\mathrm{Na} / \mathrm{Cl}$ diagram of the groundwater within UmErdhuma-Tayarat aquifer. 
may not be the major geochemical process controlling the chemistry of groundwater in the study region or ion exchange reaction dominating over evaporation.

\subsubsection{Leaching and Dissolution Weathering Minerals}

As a result of rock weathering $\mathrm{Ca}, \mathrm{Mg}, \mathrm{SO}_{4}, \mathrm{HCO}_{3}$, and $\mathrm{Cl}$ are added to water. The amount of each ion in water is dependent on the rock forming minerals.

The $\mathrm{Na} / \mathrm{Cl}$ ratio has often been used to identify the mechanism of salinity distribution [39]. The concentration of $\mathrm{Cl}$ and $\mathrm{Na}$ are probably derived from the dissolution of disseminated halite in fine-grained sediments. The high values of $\mathrm{Na} / \mathrm{Cl}$ ratios are probably originated to water rock interaction where the average value of $\mathrm{Na} / \mathrm{Cl}$ (Table 5 ) becomes greater than its value in seawater (0.87). This indicates a partial leaching and dissolution of terrestrial deposits supported by high content of sodium in $84 \%$ of groundwater samples within UmErdhuma-Tayarat aquifer. Halite dissolution may account for high concentration of $\mathrm{Cl}$, and cation exchange may account for a reduction in the Na concentration in $16 \%$ of groundwater samples. The contribution of $\mathrm{K}$ to the groundwater in these samples is low. The low levels of potassium in water are a consequence of its tendency to be fixed by clay minerals and to participate in the formation of secondary minerals [32] [40].

The molar ratio of $\mathrm{Na} / \mathrm{Cl}$ for groundwater samples generally ranges from 0.58 to 5.6 (Table 5). Most groundwater samples of aquifers have $\mathrm{Na} / \mathrm{Cl}$ ratio more than unity (67\% of water points), which reflects leaching of terrestrial salt facies (groundwater of meteoric origin) indicating that halite dissolution is the major process with some contribution of cation exchange processes. In this case, the alkalineearths ( $\mathrm{Ca}$ and $\mathrm{Mg}$ ) in solution replace the alkalis ( $\mathrm{Na}$ and $\mathrm{K}$ ) on the surface of clay minerals in the aquifer matrix. The groundwater samples of aquifers that have $\mathrm{Na} / \mathrm{Cl}$ ratio less than unity (33\% of water points), reflects leaching of marine salt facies indicating that the mixing mechanism is the major process with the fossil groundwater of marine origin.

The ratio of $\mathrm{Ca} / \mathrm{Mg}$ (Table 5) varies between 0.23 and 2.07 which exceeds that of fossil connate seawater (equal to 0.19 ). This may indicate a meteoric water origin influenced by carbonate salt dissolution where the aquifers matrix contains carbonate forms as (aragonite, calcite, and dolomite).

$\mathrm{Ca} / \mathrm{Mg}$ ratio of $17 \%$ from the groundwater samples suggests the dominance dissolution of calcite present in the aquifer, where a higher $\mathrm{Ca} / \mathrm{Mg}$ ratio $(>1)$ is indicative of greater calcite contribution [41]. Whereas a low Ca/Mgratio $(<1)$ in $83 \%$ of the groundwater samples is indicative of dolomite dissolution.

Low value of $\mathrm{SO}_{4} / \mathrm{Cl}$ ratio varies between 0.54 and 0.88 in $34 \%$ of groundwater samples within UmErdhuma-Tayarat aquifer indicates low content of sulphate salts in the leached sediments (Table 5). While high value of $\mathrm{SO}_{4} / \mathrm{Cl}$ ratio varies between 1.1 and $5.4 \%$ in $66 \%$ of groundwater samples. This indicates the high content of gypsum and anhydrite in the leached sediments.

The high values of $\mathrm{HCO}_{3} / \mathrm{Cl}$ ratio varies between 1.03 and 3.6 are indicative of freshwater recharge in $33 \%$ of water points. Generally, the ratio gradually decreases and approachs the ratio value of connate fossil water as TDS increases, indicating the mixing 
influence with fossils water in $67 \%$ of water points. Consequently, the ratio of $\mathrm{HCO}_{3} / \mathrm{Cl}$ considered as good indicator for salinization due to oil field water encroachment or mixed behavior with saltwater pockets after drilling processes (pollution case). Carbonate-rich rocks such as limestone, dolomite, and dolomitic limestone are the major sources for bicarbonate weathering and dissolution. The available bicarbonates in these rocks might have been dissolved and added to the groundwater system during rain water infiltration and groundwater movement.

\subsubsection{Ion Exchange Process}

Ion exchange process depends on replacement of adsorbed ions on the exchange complex by ions existed in solution and when fresh groundwaters flush out saline groundwaters, the reverse reactions occur. From Durov diagram, the observation indicates that reverse ion exchange is a process occurred in $26 \%$ of the monitoring wells, whereas normal ion exchange noticed in $21 \%$ wells during the study period. Cation exchange is another factor modifying groundwater quality and is one of the most important geochemical processes taking place in aquifers, according to the following process [34]:

$$
\begin{gathered}
2 \mathrm{Na}^{+}\left(\mathrm{K}^{+}\right)+\mathrm{CaX}_{2}=2 \mathrm{Na}\left(\mathrm{K}^{+}\right) \mathrm{X}+\mathrm{Ca}^{2+} \\
2 \mathrm{Na}^{+}\left(\mathrm{K}^{+}\right)+\mathrm{MgX}_{2}=2 \mathrm{Na}\left(\mathrm{K}^{+}\right)-\mathrm{X}+\mathrm{Mg}^{2+},
\end{gathered}
$$

where, $\mathrm{X}$ represents ion exchange sites in aquifer materials.

There is another several indices used for the identification of water that has undergone cation exchange processes (Matthess, 1982), these are; Alkali number expressed as $(\mathrm{Na}+\mathrm{K}) / \mathrm{Cl}$. An increase or decrease of the alkali number is mainly attributed to cation exchange that takes place. In this case, the high concentration of alkalis ( $\mathrm{Na}$ and $\mathrm{K}$ ) in their halides in solution replaces $\mathrm{Ca}$ and $\mathrm{Mg}$ existed on the surface of clay minerals in aquifer matrix. The depletion of $\mathrm{Na}$ concentration accompanied by increase of $\mathrm{Ca}$ and $\mathrm{Mg}$ concentrations in solution, leading to an increase in salts causing permanent hardness $\left(\mathrm{MgCl}_{2}, \mathrm{CaCl}_{2}, \mathrm{MgSO}_{4}\right.$ and $\left.\mathrm{CaSO}_{4}\right)$ rather than those causing temporary hardness $\mathrm{Ca}\left(\mathrm{HCO}_{3}\right)_{2}$.

The plot of $\mathrm{Ca} / \mathrm{Mg}$ versus TDS (Figure 13) shows curve trend. This relation reveals that $\mathrm{Ca}$ concentration of the groundwater samples within hydrogeologic system is slightly increased with the increasing of salinity within $1000 \mathrm{mg} / \mathrm{L}$ to $3000 \mathrm{mg} / \mathrm{L}$ represented by rational function;

$$
\mathrm{Ca} / \mathrm{Mg}=\mathrm{a}+\mathrm{b}(\mathrm{TDS})+\mathrm{c}(\mathrm{TDS})^{\wedge} 2+\mathrm{d}(\mathrm{TDS})^{\wedge} 3 .
$$

This indicates a removal of calcium ions from carbonate rocks and replaced by magnesium from groundwater throughout ion exchange reaction (dolomitization process). Another phenomenon of calcium concentration decreases with the increasing of salinity more than $3000 \mathrm{mg} / \mathrm{L}$, which indicates a removal of magnesium ions from dolomite and replaced by calcium from groundwater throughout ion exchange reaction (dedolomitization process).

Schoeller 1977 in [42] proposed chloro-alkaline index (CAI) to understand the ion exchange between the groundwater and its host environment. The chloro-alkaline 


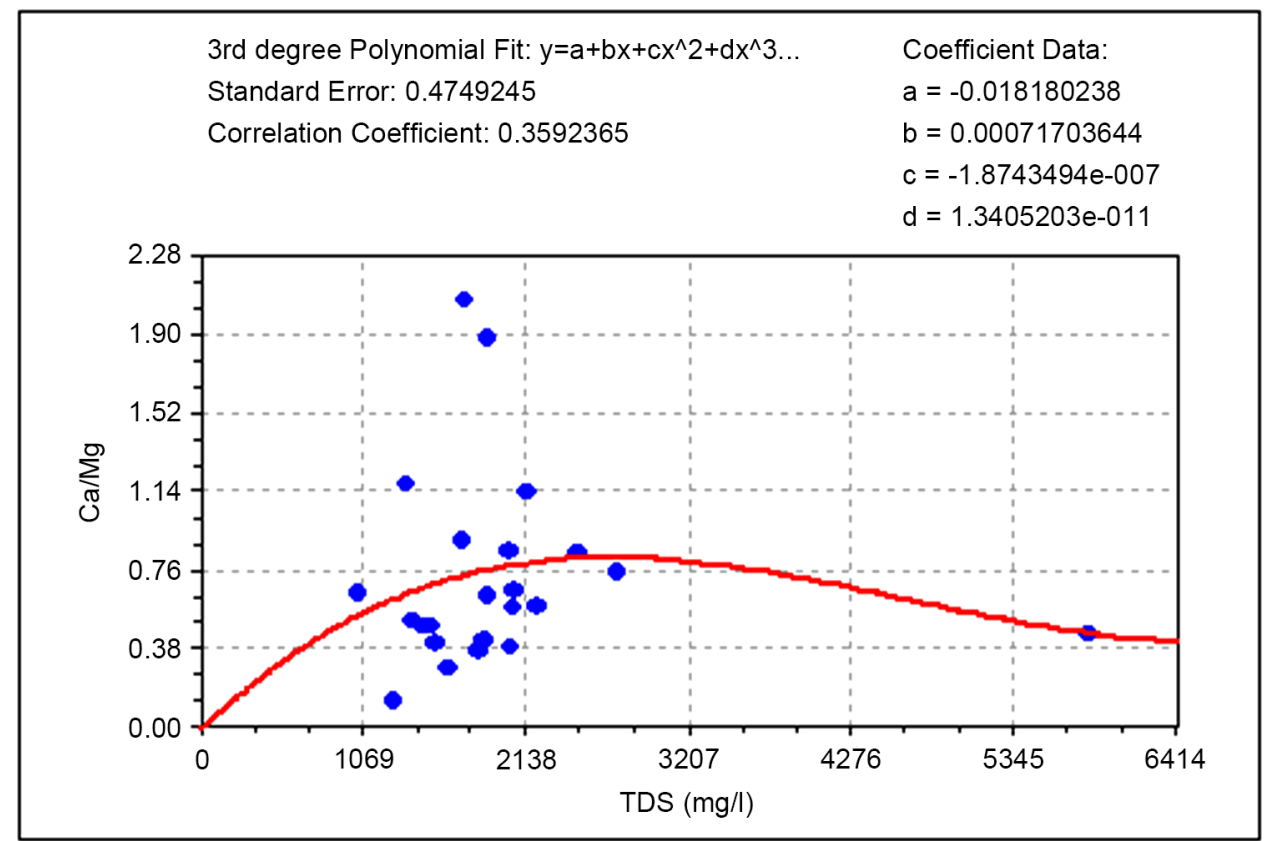

Figure 13. TDS vs. Ca/Mg scatter diagram.

indices are expressed by the following equations;

$$
\mathrm{CAI}=\mathrm{C} 1-(\mathrm{Na}+\mathrm{K}) / \mathrm{C} 1
$$

and

$$
\mathrm{CAI} 2=[\mathrm{C} 1-(\mathrm{Na}+\mathrm{K})] /\left[\mathrm{SO}_{4}+\mathrm{HCO}_{3}\right]
$$

where all values expressed in meq/l. The results of Chloro-alkaline indices for the groundwater samples of the study area (Table 5) suggest the occurrence of ion exchange process. When there is an exchange between $\mathrm{Ca}$ and/or $\mathrm{Mg}$ in the groundwater with $\mathrm{Na}$ and/or $\mathrm{K}$ in the aquifer material, the results of CAI and CAI2 indices are negative, and if there is a reverse ion exchange, the indices will be positive.

CAI and CAI2 values for the groundwater of UmErdhuma-Tayarat aquifer range from 0.06 to 0.495 and from 0.02 to 0.34 , respectively. These observations indicate that reverse ion exchange (exchange between $\mathrm{Na}$ and $\mathrm{K}$ in the groundwater with $\mathrm{Ca}$ and/or $\mathrm{Mg}$ in the aquifer material which obtained high percent of clays) is the dominant process of ion exchange in the groundwater at a percent of (33\%), whereas normal ion exchange with CAI and CAI2 values range from -0.01 to -4.6 and from -0.005 to -0.77 respectively, noticed in $67 \%$ of groundwater samples within UmErdhuma-Tayarat aquifer.

\section{Conclusions}

The study is concerned with the impact of hydrochemical processes on the groundwater quality within the aquifer. The hydrochemical processes that mostly influence the species of groundwater chemistry are leaching and dissolution of surface and subsurface weathered rocks with the effect of reverse and normal ion exchange throughout 
water-rock interaction (e.g. dolomitization and dedolomitization process). Also, the evaporation process and mixing action have a significant effect. Moreover, reduction oxidation process has no effect on the evolution of groundwater quality. Carbonate and sulphate mineral dissolution, with normal ion exchange reactions in 67 percentile of groundwater samples within UmErdhuma-Tayarat aquifer are the major hydrogeochemical processes responsible for the concentration of major ions in groundwater. Most groundwater samples of aquifer have $\mathrm{Na} / \mathrm{Cl}$ ratio more than unity (67\% of water points), reflects leaching of terrestrial salt facies (groundwater of meteoric origin). While the groundwater of aquifer that have $\mathrm{Na} / \mathrm{Cl}$ ratio less than unity (33\% of water points) reflects leaching of marine salt facies indicating that the mixing mechanism is the active process that impact the fossil groundwater of marine origin. Sulphate and chloride concentrations and depth to water table illustrates that water chemistry is impaired by land-use activities (geochemical affects with no impact of anthropogenic process). Groundwater samples of UmErdhuma-Tayarat aquifer are slightly saturated with respect to dolomite, slightly under-saturated with respect to aragonite. Fifty percent of groundwater samples are slightly saturated with respect to calcite. Whereas, all groundwater samples are slightly under saturated with respect to gypsum/anhydrite and moderately under saturated with respect to halite/sylvite. The majority of the groundwater types of UmErdhuma-Tayarat aquifer (91.5\% of the total samples) belong to intermediate-more advanced grade of metasomatic sequence obtaining $\mathrm{SO}_{4}>$ $\mathrm{HCO}_{3}>\mathrm{Cl}, \mathrm{SO}_{4}>\mathrm{Cl}>\mathrm{HCO}_{3}, \mathrm{Cl}>\mathrm{SO}_{4}>\mathrm{HCO}_{3}$, and $\mathrm{Cl}>\mathrm{HCO}_{3}>\mathrm{SO}_{4}$ water types.

The first main conclusion that can be extracted from the hydrochemical interpretation strongly illustrates that rational plan for long-term and sustainable management of UmErdhuma-Tayarat aquifer cannot be only based on regulatory water quality targets.

So, a successful aquifer management plan will need to consider, the degree to which various waters currently encountered in the aquifer has complex mixtures between modern recharge waters, and ancient trapped fossil waters. The evolution of groundwater in the area could be explained, also by hydraulic properties and hydrodynamic behavior, such as groundwater flow through the strata of different mineralogical composition.

\section{References}

[1] Hussien, B., Fayyadh, A. and Nafi, N. (2013) An Integrated Hydrogeological Approach for Aquifers Systems and Groundwater Flow within Nukhaib-Km.160 Region (West Iraq). Journal of University of Anbar for Pure Science, accepted.

[2] Hamza, N. (1997) Geomorphological Map of Iraq. GEOSURV, Baghdad. (Scale 1:1000 000)

[3] Jasim, S. and Goff, J. (2006) Geology of Iraq. Dolin, Prague \& Moravian Museum Brno.

[4] Al-Mubarak, M. and Amin, R. (1983) Report on the Regional Geological Mapping of the Eastern Part of the Western Desert and Western Part of the Southern Desert. GEOSURV, Internal Report No. 1380.

[5] Al-Bassam, S., Al-Azzawi, A., Dawood, R. and Al-Bedaiwi, J. (2000) Subsurface Study of the Pre-Cretaceous Regional Unconformity in the Western Desert of Iraq. Iraqi Geological Journal, 32/33, 1-25. 
[6] Al-Mubarak, M. (1996) Regional Geological Setting of the Central Part of the Iraqi Western Desert. Iraqi Geological Journal, 29, 64-83.

[7] Buday, T. and Hack, J. (1980) Report on Geological Survey of the Western Part of the Western Desert, Iraq. GEOSURV, Internal Report No. 1000, Iraq.

[8] Jasim, S., Karim, S., Basi, M., Al Mubarak, M. and Mansour, J. (1984) Final Report of the Regional Geological Survey of Iraq. GEOSURV, Vol. 3.

[9] Al-Naqib, S., Said, I., Taha, Y., Al-Sharbati, F., Yakta, S., Hussien, M., Yacob I. and AlMukhtar, L. (1986) Detailed Geological Survey of Rutba Area. GEOSURV, Internal Report No. 1560.

[10] Al-Azzawi, A. and Dawood, R. (1996) Report on Detailed Geological Survey in North West of Kilo-160, Rutba Area. GEOSURV, Internal Report No. 2491.

[11] Sessakian, V. and Mohamed, B. (2007) Stratigraphy of the Iraqi Western Desert. IBGM.

[12] Yacob, S. (1995) Geology of Tebal Valley. Iraqi Geological Survey and Mining, GEOSURV, Internal Report No. 2400.

[13] Al-Shamma, A. (1993) Hydrogeological and Tectonic Investigation of the Southern Part of the Western Desert. Unpublished Thesis, University of Baghdad, College of Science, Baghdad.

[14] Hussien, B. (2010) Hydrogeological Condition within Al-Anbar Governorate. Journal of University of Anbar for Pure Science, 4, 97-111.

[15] Laboutka, M. (1974) The Hydrogeological Tables and Data. The Basic Instructions No. 3 Report No. 8, National Iraqi Minerals Company, Baghdad.

[16] Hussien, B. and Fayyadh, A. (2014) Preferable Districts for Groundwater Exploitation Based on Hydrogeologic Data of Aquifers-West Iraq. Journal of Water Resource and Protection, 6, 1173-1197. http://www.scirp.org/journal/jwarp http://dx.doi.org/10.4236/jwarp.2014.612108

[17] Yugoslavia, C. (1981) Regional Hydro Geological Study for Block No. 5 (Rutba Area) \& for Block No. 7 (Ramadi-Ana-K-160). Unpublished Study, Ministry of Irrigation.

[18] Al-Jabbari, M., Hassan, Q. and Imad, M. (2002) The Water Resources in Euphrates Basin. Unpublished Study, Ministry of Agriculture, 524 p.

[19] Todd, D. and Mays, L. (2005) Ground Water Hydrology. John Wiley and Son Inc., New York.

[20] Huisman, L. (1972) Groundwater Recovery. Macmillan Publishers, London.

[21] Fitts, C. (2002) Groundwater Science. Elsevier Science Ltd., Amsterdam, 450 p.

[22] Barcelona, J., Gibb, P., Helfrich, A. and Garske, E. (1985) Robert S. Kerr Environnemental Research Center. Practical Guide for Groundwaters Sampling, EPA-600u2-85104, USEP Agency, 78-80.

[23] USEPA (1989) Intérim Final Guidance on Statistical Analysis of Groundwater Monitoring Data at RCRA Facilities.

[24] Plazak, D. (1994) Differences between Water Level Probes, GW. Monitoring and Remediation, 14, 84 p.

[25] Nielsen, D. (2006) The Practical Handbook of Environ-mental Site Characterization and Groundwaters Monitoring. 2nd Edition, CRC Press/Taylor and Francis Group, Boca Raton, $1318 \mathrm{p}$.

[26] Shelton, L. (1994) Field Guide for Collecting and Processing Stream-Water Samples for the National Water Quality Assessment Program. USGS Open-File Report 94-455, US Geological Survey, Sacramento. 
[27] USEPA (2000) National Water Quality Inventory: 2000 Report. EPA-841-R-02-001.

[28] Shafer, M., Overdier, J., Hurley, J., Armstrong, D. and Webb, D. (1997) The Influence of Dissolved Organic Carbon, Suspended Particulates, and Hydrology on the Concentration, Partitioning and Variability of Trace Metals in Two Contrasting Watersheds (USA). Chemical Geology, 136, 71-97. http://dx.doi.org/10.1016/S0009-2541(96)00139-8

[29] Hem, J. (1990) Study and Interpretation of the Chemical Characteristics of Natural Water. 3rd Edition, USGS Water Supply.

[30] Gonzalez-Ramón, A., Lopez-Chicano, M. and Rubio-Campos, J. (2012) Piezometric and Hydrogeo-Chemical Characterization of Groundwater Circulation in Complex Karst Aquifers. A Case Study: The Mancha Real-Pegalajar Aquifer (Southern Spain). Environmental Earth Sciences Journal, 67, 923-937. http://dx.doi.org/10.1007/s12665-012-1529-y

[31] Parkhurst, D. and Appelo, C. (1999) User's Guide to PHREEQC (Version 2)—A Computer Program for Speciation, Batch-Reaction, One-Dimensional Transport, and Inverse Geochemical Calculations. USGS Water-Resources Investigations Report 99-4259, Petalas.

[32] Matthess, G. (1982) The Properties of Groundwater. Department of Environmental Science, John Wiley and Sons Inc., New York, 406 p.

[33] Collin's, A. (1975) Geochemistry of Oil Field Water Vol.1: Development in Petroleum Science. Elsevier Science, Amsterdam, 496 p.

[34] Appelo, C. and Postma, D. (2005) Geochemistry, Groundwater and Pollution. 2nd Edition, Balkema, Rotterdam. http://dx.doi.org/10.1201/9781439833544

[35] Gibbs, R. (1970) Mechanisms Controlling World Water Chemistry. Science, 170, 795-840. http://dx.doi.org/10.1126/science.170.3962.1088

[36] Stumm, W. and Morgan, J. (1981) Aquatic Chemistry. John Wiley and Sons, Hoboken.

[37] Deutsch, W. (1997) Groundwater Geochemistry: Fundamentals and Applications to Contamination. Lewis Publishers, New York.

[38] Jankowski, J. and Acworth, R. (1997) Impact of Debris Flow Deposits on HydrogeoChemical Process and the Development of Dry Land Salinity in the Yass River Catchment, New South Wales, Australia. Hydrogeology Journal, 5, 71-88. http://dx.doi.org/10.1007/s100400050119

[39] Sami, K. (1992) Recharge Mechanisms and Geochemical Processes in a Semi-Arid Sedimentary Basin, Eastern Cape, South Africa. Journal of Hydrology, 139, $27-48$. http://dx.doi.org/10.1016/0022-1694(92)90193-Y

[40] Zhu, G., Su, Y. and Feng, Q. (2008) The Hydrogeochemical Characteristics and Evolution of Groundwater and Surface Water in the Heihe River Basin, Northwest China. Hydrogeology Journal, 16, 167-182. http://dx.doi.org/10.1007/s10040-007-0216-7

[41] Maya, A. and Loucks, M. (1995) Solute and Isotopic Geochemistry and Groundwater Flow in the Central Wasatch Range, Utah. Journal of Hydrology, 172, 31-59. http://dx.doi.org/10.1016/0022-1694(95)02748-E

[42] Schoeller, H. (1977) Geochemistry of Groundwater. In: Groundwater Studies-An International Guide for Research and Practice. UNESCO, Paris, Ch. 15, 1-18. 
Submit or recommend next manuscript to SCIRP and we will provide best service for you:

Accepting pre-submission inquiries through Email, Facebook, LinkedIn, Twitter, etc. A wide selection of journals (inclusive of 9 subjects, more than 200 journals)

Providing 24-hour high-quality service

User-friendly online submission system

Fair and swift peer-review system

Efficient typesetting and proofreading procedure

Display of the result of downloads and visits, as well as the number of cited articles

Maximum dissemination of your research work

Submit your manuscript at: http://papersubmission.scirp.org/

Or contact ijg@scirp.org 